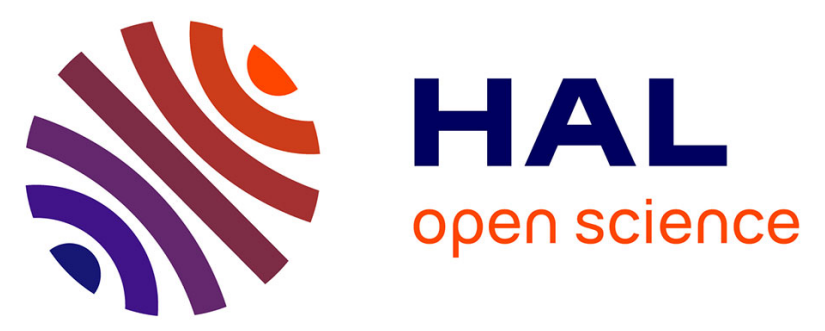

\title{
A 3-year follow-up of indoor air quality and comfort in two energy-efficient houses
}

Mickaël Derbez, Bruno Berthineau, Valérie Cochet, Cécile Pignon, Jacques Ribéron, Guillaume Wyart, Corinne Mandin, Séverine Kirchner

\section{To cite this version:}

Mickaël Derbez, Bruno Berthineau, Valérie Cochet, Cécile Pignon, Jacques Ribéron, et al.. A 3-year follow-up of indoor air quality and comfort in two energy-efficient houses. Building and Environment, 2014, 82, pp.288 - 299. 10.1016/j.buildenv.2014.08.028 . hal-01102220

\section{HAL Id: hal-01102220 \\ https://hal-cstb.archives-ouvertes.fr/hal-01102220}

Submitted on 12 Jan 2015

HAL is a multi-disciplinary open access archive for the deposit and dissemination of scientific research documents, whether they are published or not. The documents may come from teaching and research institutions in France or abroad, or from public or private research centers.
L'archive ouverte pluridisciplinaire HAL, est destinée au dépôt et à la diffusion de documents scientifiques de niveau recherche, publiés ou non, émanant des établissements d'enseignement et de recherche français ou étrangers, des laboratoires publics ou privés. 


\section{Accepted Manuscript}

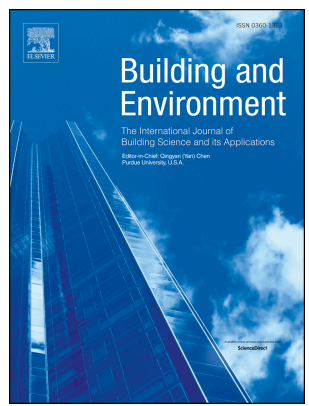

A 3-year follow-up of indoor air quality and comfort in two energy-efficient houses

Mickaël Derbez, Bruno Berthineau, Valérie Cochet, Cécile Pignon, Jacques Ribéron, Guillaume Wyart, Corinne Mandin, Séverine Kirchner

PII: S0360-1323(14)00287-X

DOI: $\quad$ 10.1016/j.buildenv.2014.08.028

Reference: BAE 3812

Published in : Building and Environment, 82, December 2014, p. 288-299

Received Date: 24 June 2014

Revised Date: 25 August 2014

Accepted Date: 27 August 2014

Please cite this article as: Derbez M, Berthineau B, Cochet V, Pignon C, Ribéron J, Wyart G, Mandin C, Kirchner S, A 3-year follow-up of indoor air quality and comfort in two energy-efficient houses, Building and Environment 82 (2014) 288-299, doi: 10.1016/j.buildenv.2014.08.028.

This is a PDF file of an unedited manuscript that has been accepted for publication. As a service to our customers we are providing this early version of the manuscript. The manuscript will undergo copyediting, typesetting, and review of the resulting proof before it is published in its final form. Please note that during the production process errors may be discovered which could affect the content, and all legal disclaimers that apply to the journal pertain. 


\section{A 3-year follow-up of indoor air quality and comfort in two energy-efficient houses}

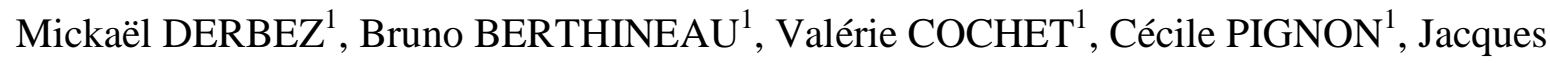
RIBÉRON $^{1}$, Guillaume WYART ${ }^{1}$, Corinne MANDIN ${ }^{1}$, Séverine KIRCHNER ${ }^{1}$

${ }^{1}$ Paris-Est University, Scientific and Technical Center for Building (CSTB), Health and Comfort Direction, French Indoor Air Quality Observatory (OQAI), 84, avenue Jean Jaurès Champs sur Marne, 77447 Marne la Vallée cedex 2, FRANCE

\section{Mickaël DERBEZ}

Université Paris-Est

Centre Scientifique et Technique du Bâtiment (CSTB)

Direction Santé-Confort - Observatoire de la Qualité de l'Air Intérieur (OQAI)

84, avenue Jean Jaurès - Champs sur Marne

77447 Marne la Vallée cedex 2

\section{FRANCE}

Tel.: +33(0)-1-64-68-89-89

Fax.: +33(0)-1-64-68-88-23

email: mickael.derbez@cstb.fr 


\section{Highlights:}

- Indoor environmental quality (IEQ) in energy-efficient houses was studied over time

- IEQ was generally acceptable over time except when ventilation systems were shut down

- More quiet, user-friendly and robust ventilation systems have to be developed

- Inspection of ventilation systems and frequent maintenance by professional should be mandatory

- Information should be provide to the user to avoid some behaviour leading to poor IEQ 


\section{Abstract}

In order to improve the knowledge of the indoor environment quality of energy-efficient buildings, a 3-year follow-up study was carried out in two wooden-framed low-energy singlefamily houses in France. Several indoor air indicators and indoor environmental parameters were measured during seven weeks in total from the pre-occupancy stage up to three years of occupancy. Questionnaires were used for each investigation to record the family activities and perceived comfort of occupants. The ventilation systems presented some shortcomings, including the failure to reach the designed exhaust air flow rate and induced occupant dissatisfaction. Regarding the measured pollutants, both houses didn't present any specific indoor air pollution. The variability of indoor air quality over time was explained by the high emissions from the new building materials, products, and paints during the first months after completion and then more episodically by human activities during occupancy. Regarding the thermal comfort and even if occupants were globally satisfied, overheating and underheating were observed. According to our results and in order to guarantee the health and the wellbeing of occupants in these buildings, it would be useful to integrate the solar shadings at the very first stage of the building design, to design more quiet, user-friendly and robust ventilation systems and to implement mandatory inspection as well as frequent maintenance by professionals and finally to promote the labelling of low-emitting construction and decoration products, furniture and consumer products.

Key words: aldehyde, volatile organic compound, particle, thermal comfort, mechanical ventilation, wooden detached house 


\section{Introduction}

The impact of global warming due to anthropogenic greenhouse gas emissions has promoted energy efficiency and support for renewable products around the world. In France, the government has pledged to cut its greenhouse gas emissions by four-fold from the 1990 baseline by 2050 . For the existing buildings, the government has committed an extensive program to reducing their energy consumption by $38 \%$ between 2009 and 2020 [1]. For the new buildings (built after January $1^{\text {st }}, 2013$ ), the enforcement of the 2012 Thermal Regulation (RT 2012) aims to generalize energy-efficient buildings with a reinforced airtight envelope [2]. Following the reinforcement of the Thermal Regulation, especially between 2000 and 2012, the required primary conventional energy consumption of the new buildings was divided by about four: from $190 \mathrm{kWh} / \mathrm{m}^{2}$ per year to less than $50 \mathrm{kWh} / \mathrm{m}^{2}$ per year. Over the same period, the required air leakage rate of the envelope was divided by two: from about 4 $\mathrm{ACH}$ at $50 \mathrm{~Pa}$ to less than $2 \mathrm{ACH}$ at $50 \mathrm{~Pa}$ for single-family houses. Buildings are now built with much higher airtightness requirements in order to prevent uncontrolled ventilation heat losses. In order to satisfy energy performance and ventilation requirements, the mechanical ventilation systems are increasingly used. Moving from buildings with infiltration rate by air leakage to airtight buildings mainly mechanically ventilated is a large step change in terms of culture. There are increasing concerns regarding the impact of the airtight construction on health and well-being of the occupants such as the possible degradation of the indoor environment quality (IEQ), the effectiveness of the mechanical ventilation system in maintaining healthy indoor environment, the potential impact of occupants behaviour on the operation of the equipment (ventilation, heating, cooling,etc). To date few data on indoor air quality (IAQ) in energy-efficient buildings is available. A first review on IAQ in energy efficient buildings concluded that further researches are needed [3]. More recently, a review of the background information regarding low-carbon housing in the United Kingdom [4] cited 
just one study conducted in four energy-efficient houses [5]. Some authors [6] reported in a review of case studies published between 2008 and 2013 in ASHRAE's "High Performing Buildings" magazine that most of these studies mentioned IAQ design construction but generally did not provide measured IAQ data. In the same year, research priorities focusing on IAQ in highly energy-efficient buildings were proposed to fill the gap of knowledge and take into account the health and comfort of the occupants of these future buildings [7]. In conclusion, data relative to IAQ and more generally to IEQ in energy efficient buildings are urgently needed to have an overview of any possible problems in such buildings to rapidly adjust the building practices and/or occupants' habits.

In this context, the French Indoor Air Quality Observatory (OQAI) has launched a specific research program dedicated to IAQ and comfort in energy efficient buildings. A first study was carried out in seven energy-efficient newly built houses (house "A" to house G") before and during the houses' first year of occupancy [8]. It provided the indoor concentrations of some pollutants such as volatile organic compounds, aldehydes and particles and made possible to find some hypotheses concerning the pollutants sources. Although the ventilation systems allowed an air exchange rate of $0.5 \mathrm{~h}^{-1}$ and higher, some shortcomings were reported and occupants complained about noise annoyances and complexity of use. No conclusions were drawn on the potential changes of the IEQ over time because the measurements and observations were carried out in a relatively short period of time and were not repeated. The monitoring was extended by two supplementary years in two of these houses (house "B" and house "E") to study the potential changes over time of ventilation conditions and IEQ parameters and to consolidate the first results.

This three-year follow-up study aims specifically to: 
- follow the operation of the ventilation system over time and to collect regularly the feedbacks of occupants relating to the acoustic comfort, the use and the maintenance of this system,

- describe the time trends in indoor concentrations over a long period,

- describe the thermal comfort during repeated seasons in these buildings in which heating and cooling energy use are reduced.

In addition this three-year follow-up study completes, with additional parameters and over a longer period, the results provided by the rare previous longitudinal studies of IAQ in energyefficient houses [5, 9, 10, 11, 12].

\section{Materials and methods}

\subsection{Description of the measurement sites}

Two single-family detached houses (house "B" and house "E") located in the western area of France (Pays-de-la-Loire) were investigated in this study (Table 1). They were built in 2009 within the requirements of the former French 2005 Thermal Regulation (RT 2005) but can be considered as highly energy-efficient homes as defined by the RT 2012, in particular because of their high airtightness levels and their low theoretical energy consumption. These houses were part of the earliest energy-efficient houses built in France. Their inhabitants (architects of the building) were aware of IAQ and have chosen low-emission building products to avoid indoor air pollution.

Table 1 - Main characteristics, occupation description of both single-family detached houses (n.e.: not estimated)

\subsection{Measurement protocol}


The IAQ was monitored immediately after the completion of the houses, from June/July 2009 to January 2012 (Table 2). Seven weeks of measurements were performed for each house: one week in the pre-occupancy stage and six weeks over 3 years in the occupancy stage during summer (2009, 2010, and 2011) and in winter (2009-2010, 2010-2011, and 2011-2012). The thermal comfort parameters were measured in the occupancy stage during each weekly investigation and, in addition, the temperature was measured continuously until December 2012. The exhaust air flow rate was measured in the pre-occupancy stage and twice in the occupancy stage (winter 2010-2011 and winter 2011-2012). The sound pressure level generated by the mechanical ventilation with heat recovery (MVHR) was measured one time during the occupancy stage (winter 2011-2012).

Table 2 - Weekly mean outdoor temperature $\left({ }^{\circ} \mathrm{C}\right) \pm$ standard deviation, moving dates and weekly investigation dates of the IAQ and thermal comfort parameters in the pre-occupancy stage and in the occupancy stage of both houses (n.a.: not available)

The measurement protocols for assessing IAQ and thermal comfort have been previously presented in detail $[8,13]$. Briefly, the IAQ parameters were measured weekly on-line as follows: 1) the total volatile organic compounds (TVOC in $\mu \mathrm{g} / \mathrm{m}^{3}$ toluene equivalent; uncertainty of $\pm 38 \mu \mathrm{g} / \mathrm{m}^{3}$ ) were measured every 10 minutes with a photoionisation detector (PGM 7240 - RAE Systems); 2) the carbon dioxide $\left(\mathrm{CO}_{2}\right.$ in ppm; uncertainty of $\pm 3 \%$ of reading $+50 \mathrm{ppm}$ ) was measured every 10 minutes by a non-dispersive infrared probe (TSI QTrak 8552); 3) the number of particles $/ \mathrm{cm}^{3}$ (diameter: 0.3-20 $\mu \mathrm{m}$ ) was measured every 10 minutes by an optical portable aerosol spectrometer (dust monitor 1.108 - Grimm,); and 4) the carbon monoxide ( $\mathrm{CO}$ in $\mathrm{ppm}$; uncertainty of $\pm 3 \mathrm{ppm}$ ) was measured every 5 minutes with an electrochemical sensor (gas monitor Draeger Pac III). The target volatile organic 
compounds (VOCs) and aldehydes were sampled by diffusive samplers over 7 days $\left(\right.$ Radiello $^{\circledR}$ ) and were analysed and quantified in $\mu \mathrm{g} / \mathrm{m}^{3}$ by gas chromatography, mass spectrometry and flame ionisation, and high-performance liquid chromatography with detection by UV absorption respectively. The analytical uncertainties were estimated to be $15 \%$ for the VOCs and $10 \%$ for the aldehydes. These compounds were measured following the same protocols as those implemented in the national survey on IAQ in French dwellings conducted by OQAI [14]. All the analytical methods and the detection limits for each compound have been previously detailed [15]. All other organic compounds whose concentrations exceeded $1 \mu \mathrm{g} / \mathrm{m}^{3}$ were identified and quantified as $\mu \mathrm{g} / \mathrm{m}^{3}$ toluene equivalent. For the statistical calculation, each concentration of these organic compounds below the limit of quantification (LOQ) was replaced by $\mathrm{LOQ} / 2$, and each value below the limit of detection (LOD) was replaced by zero. The mass concentrations of $\mathrm{PM}_{2.5}\left(\mu \mathrm{g} / \mathrm{m}^{3}\right)$ were sampled with a sampling system (Chempass, Model. 3400, Thermo Fisher Scientific) coupled to an air sampler (Microvol 1100, Ecotech) on Teflon filters at $1.8 \mathrm{l} / \mathrm{min}$ from $5 \mathrm{pm}$ to $8 \mathrm{am}$ on weekdays and for 24 hours per day on weekends and then weighed in the laboratory (uncertainty of $\pm 13 \mu \mathrm{g} / \mathrm{m}^{3}$ ). The outdoor mass concentrations of $\mathrm{PM}_{2.5}$ were collected from the continuous measurements made by the air quality monitoring network of the Pays-de-laLoire region (Air Pays-de-la-Loire). The indoor temperature $\left(\mathrm{T}\right.$ in $\left.{ }^{\circ} \mathrm{C}\right)$ and relative humidity (RH in \%) were measured during occupancy during each week of investigation with Hydrolog sensors (Rotronic, uncertainty of $\pm 0.3^{\circ} \mathrm{C}$ and $\pm 1.5 \% \mathrm{RH}$ at $23^{\circ} \mathrm{C}$ ). Outdoor and indoor temperatures were continuously measured from January 2010 to December 2012 with wireless temperature sensors. Because MVHR systems are not often checked during/after the completion of the building, we decided to measure the exhaust air flow rate in order to compare it with the designed exhaust air flow rate and to determine the noise level generated by the ventilation systems. The exhaust air flow rate (1/s) and the sound pressure level (LAeq 
in $\mathrm{dB}(\mathrm{A})$ ) were occasionally measured for each fan speed of the MVHR system, respectively, by an array of hot wires (Swemaflow 233, Admi Industries, uncertainty of $4 \%$ of the measured value with a minimum of $1 \mathrm{l} / \mathrm{s}$ ) and by a type 1 integrating-averaging sound level meter (Bruel \& Kjaer, Type 2250, uncertainty of $\pm 0.3 \mathrm{~dB}$ ).

The main bedroom and the open kitchen to the living room (called kitchen/living room) of each house were investigated. The passive sampling systems (VOCs and aldehydes) were installed in the main bedroom, while other noisy and bulky measurement devices (TVOC, $\mathrm{PM}_{2.5}$, and particle number) were placed in the kitchen/living room. The $\mathrm{CO}$ concentrations were measured only during the heating season in each room equipped with combustion equipment. The air temperature, relative humidity, and $\mathrm{CO}_{2}$ concentrations were measured in both rooms during each weekly investigation. Additional continuous measurements of the air temperature were made in a second bedroom, in the office, and outdoors from January 2010 (April 2010 for house E) to December 2012. The exhaust air flow rate and the sound pressure level were measured, respectively, for each accessible outlet and in each room.

The MVHR systems were switched on at the medium fan speed during the pre-occupancy investigations and then in manual or automatic mode during occupancy. For house E, these instructions were not followed correctly during the pre-occupancy stage because the occupants were present during the first $24 \mathrm{~h}$, and they switched off the MVHR system before leaving their house. MVHR system adjustments were performed before the pre-occupancy stage for house B and immediately before the first week of the occupancy stage (summer 2009) for house $E$.

\subsection{Survey questionnaires}

Concurrent with sampling and measuring, two questionnaires were developed based on the national survey on indoor air quality in French dwellings [16]. They were fulfilled by 
occupants at the end of each investigation. The first questionnaire recorded the occupancy, the use and the maintenance of the ventilation system, the use of the heating system, the window opening all day long, the presence of smokers, the installation of new furniture, the arrangement or decoration works, and the use of products known as sources of indoor air pollutants such as incense, candles, air fresheners, fragrances, pesticides, cleaning products, etc. The second questionnaire provided the perceived comfort of occupants on air stuffiness, thermal comfort and acoustic comfort and the reasons of the discomfort if any.

\section{Results}

\subsection{Ventilation systems: air flow rate, use, and maintenance}

Table 3 presents the measured exhaust air flow rate for each house in different service rooms. The decrease in the time of the air flow rate for two rooms of house $\mathrm{B}\left(2^{\text {nd }}\right.$ bathroom and the kitchen/living room) during winter 2010-2011 was linked to the outlet filters not being cleaned since the installation of the ventilation system (1.5 years prior). After cleaning, second measurements were made in the kitchen/living room, and, as expected, the air flow rate increased. The measured air flow rates were compared to the preliminary design values given by the consulting firm. The designed air flow rate was reached for house B, except for in the kitchen/living room, but never for house E, despite adjusting the MVHR system.

Table 3 - Measured air exhaust rate (1/s) per room as a function of the fan speed of the MVHR system and comparison to the designed air exhaust rate for the medium fan speed for both houses (n.m.: not measured)

The continuous A-weighted sound pressure level was measured during the winter 2011-2012 stage in different rooms for each house (Table 4). The sound pressure levels were lower for 
house $\mathrm{E}$ than for house B. In both houses, the sound pressure level measured in each room increased according to the fan speed of the MVHR system. The utility room where the MVHR system was located was the noisiest room as expected. In house B and for the high fan speed, the sound pressure level exceeded $30 \mathrm{~dB}(\mathrm{~A})$ and more than $35 \mathrm{~dB}(\mathrm{~A})$ in the bedrooms.

Table 4 - Measured continuous A-weighted sound pressure level or LAeq $(\mathrm{dB}(\mathrm{A}))$ between 50 and $1000 \mathrm{~Hz}$ per room as a function of the fan speed of the MVHR system for both houses during winter 2011-2012 (n.m.: not measured)

At the beginning of the survey, the occupants complained about the complexity of use of the MVHR system (even with the manual) and about the weekly programmed timer because the clock-switched speed changes did not match their lifestyle. The manufacturer of the MVHR system proposed to use the low fan speed during inoccupancy or during the night, the medium, most of the day and the high, during intense cooking or party. At the end of the survey, the inhabitants of house B mainly used the MVHR system in the manual mode because they were still unable to change the program. They reported that a re-adjustment of the MVHR system was necessary. The inhabitants of house E used the default program mode until summer 2011 and then succeeded in matching the program mode with their own lifestyle. In terms of maintenance, the occupants of both houses were used to changing the heat recovery filters every 6 months, but only the occupants of house E cleaned or changed the kitchen and bathrooms extract filters.

\subsection{Air stuffiness and indoor air quality}

During occupancy, the weekly median $\mathrm{CO}_{2}$ levels were lower than $840 \mathrm{ppm}$ in the main bedroom and in the kitchen/living room and showed a seasonal variation (Figure 1) in both houses. These levels were approximately 300 ppm higher in winter than in summer. The 
median $\mathrm{CO}_{2}$ concentration was similar in both rooms, taking into account the measurement uncertainties, except for in winter 2010-2011 in house B.

Figure 1 - Weekly median $\mathrm{CO}_{2}$ concentration (ppm) measured in the main bedroom (black columns) and in the kitchen/living room (grey columns) of each occupied house season (n.a.: not available).

The median level of TVOCs and the concentration of sixteen VOCs and six aldehydes most frequently detected in at least $50 \%$ of the samples are presented in Table 5. Nine organic compounds were always quantified (quantification frequency $=100 \%$ ) in the occupancy phase (from high to low concentrations: hexaldehyde, formaldehyde, acetaldehyde, alphapinene, limonene, toluene, 1,2,4-trimethylbenzene, m-p xylenes, and acrolein). Among these nine most frequently quantified organic compounds, the three aldehydes and the two terpenes presented the highest median concentrations in both occupied houses. The concentrations of the majority of these VOCs and aldehydes were higher before occupancy than after for both houses, most likely because these compounds were off-gassed from various brand new indoor structural and interior materials, whose emission intensity is highest just after house completion. The highest concentrations of TVOC, VOCs, and aldehydes were measured during the pre-occupancy stage in house E, possibly because the MVHR system was accidentally switched off during the main part of the measurement period. The air renewal was low without the ventilation system and while the windows were closed because of the absence of occupants.

Table 5 - Indoor TVOC, VOC and aldehyde levels $\left(\mu \mathrm{g} / \mathrm{m}^{3}\right)$ measured weekly in the main bedroom of each house at the pre-occupancy stage and during occupancy by season. LOD: 
limit of detection; LOI: limit of identification $(<1 \mu \mathrm{g} / \mathrm{m} 3)$; LOQ: limit of quantification; n.a.: not available

The CO concentrations measured in winter near the wood stove located in the kitchen/living room of each house were quasi-systematically equal to zero ppm. A few peaks of concentrations less than $20 \mathrm{ppm}$ were episodically measured in winter 2010-2011 and winter 2011-2012 for house B and in winter 2011-2012 for house E, early in the morning (approximately $7 \mathrm{am}$ ) or late in the evening (after $9 \mathrm{pm}$ ).

The $\mathrm{PM}_{2.5}$ mass concentration and the median number of particles measured during the preoccupancy stage and during occupancy are shown in Table 6 . The measured values were higher during occupancy than before, except for the number of particles in house $\mathrm{E}$ when the ventilation system was switched off during the pre-occupancy stage. During occupancy, the measured values were higher in winter than in summer, although all the data were not available for both houses.

Table 6 - Weekly $\mathrm{PM}_{2.5}$ mass concentration $\left(\mu \mathrm{g} / \mathrm{m}^{3}\right)$ and median number of particles $\left(\right.$ particle $\left./ \mathrm{cm}^{3}\right)$ measured in the kitchen/living room at each house at the pre-occupancy stage and during occupancy by season. (n.a.: not available)

\subsection{Indoor climate conditions}

During each week of investigation, the indoor air temperature and the relative humidity were measured in the main bedroom and the kitchen/living room of each house. The absolute humidity, expressed as the ratio of water vapour-to-unit mass of dry air $(\mathrm{g} / \mathrm{kg})$, was calculated according to these parameters. Table 7 shows that the mean indoor air temperature was higher in house $\mathrm{B}$ than in house $\mathrm{E}$ regardless of the season. The mean values were higher than $23^{\circ} \mathrm{C}$ for house $\mathrm{B}$ and $21^{\circ} \mathrm{C}$ for house $\mathrm{E}$ in the summer period and lower than $22^{\circ} \mathrm{C}$ for house $\mathrm{B}$ and 
$19^{\circ} \mathrm{C}$ for house $\mathrm{E}$ in the winter period. The absolute humidity was higher than $8 \mathrm{~g}$ vapour $/ \mathrm{kg}$ dry air in the summer period and lower than this in the winter period.

Table 7 - Weekly mean indoor temperature $\left({ }^{\circ} \mathrm{C}\right)$ and absolute humidity $(\mathrm{g} / \mathrm{kg}) \pm$ standard deviation measured in the main bedroom and in the kitchen/living room at each house during occupancy by season. (n.a.: not available)

To assess the thermal comfort conditions, the indoor air temperature measured in both houses over 2 years was compared to two threshold temperatures. These threshold temperatures were set based on human thermal comfort temperature range: a "hot" threshold temperature being at $27^{\circ} \mathrm{C}$ and a "cold" threshold temperature being at $16^{\circ} \mathrm{C}$. This range refers to advisory values from energy providers, shifted in economic mode, in the "worst case" type of room. The percentage of time above $27^{\circ} \mathrm{C}$ or below $16^{\circ} \mathrm{C}$ was calculated for each month only during occupancy. Figure 2, relative to the indoor temperature measured in the kitchen/living room where the wood stove was located, shows that thermal discomfort was observed in winter and in summer for both houses. During the heating season (between October and April), the percentage of time with indoor temperatures below $16^{\circ} \mathrm{C}$ was lower and occurred more sporadically for house B than for house E. Overheating was observed in the summer months (between May and September) regularly in house B and only occasionally in summer 2010 in house E.

Figure 2 - Percentage of time per month when the indoor temperature measured in the kitchen/living room of house $\mathrm{B}$ (upper) and house $\mathrm{E}$ (lower) was below $16^{\circ} \mathrm{C}$ (black columns) or above $27^{\circ} \mathrm{C}$ (grey columns) over 2 years. 


\subsection{Perceived comfort by occupants}

According to the perception questionnaire, the occupants of both houses were "rather satisfied" with the thermal comfort but highlighted some dissatisfaction. In winter, they complained of cool mornings when the heating system was turned off during the night and was not functioning when they woke up. They complained about the inhomogeneous heat distribution in the house leading to higher temperature in the room containing the stove and temperature default in coldest rooms (bedrooms, office). In summer, only the occupants of house $\mathrm{B}$ complained of having high temperature in the living/room and in the bedrooms especially at the end of afternoon. With regard to the acoustic comfort, they were from « rather satisfied» to «highly satisfied» most of the time; the occupants of house B complained about noise annoyance when the ventilation system operated with high fan speed.

\section{Discussion}

\subsection{Operation and use of ventilation systems}

Some of the shortcomings of the MVHR systems highlighted in this study were consistent with those reported in recently built Dutch homes [17, 18] and in zero-carbon homes [10, 19] equipped with these systems. Regarding the noise annoyance generated by the ventilation system, the high sound levels measured were consistent with the occupants' dissatisfaction. Some authors reported that noise from the ventilation system was a nuisance when the systems operated with higher air flows [20]. Moreover, more user-friendly and robust ventilation systems are needed, as reported in another study [21], and their maintenance should be assured by qualified professionals rather than by the occupants, who are not always motivated or able to correctly maintain the system. 


\section{ACCEPTED MANUSCRIPT}

\subsection{Comparison of IAQ with other studies in newly built energy-efficient wooden frame houses}

Before describing in detail the time trends of indoor pollutants concentrations, it appears useful to compare our results with those reported from previous studies carried out in similar airtight homes i.e. newly built, wooden frame energy-efficient dwellings [5, 9, 10, 11, 12, 22]. For this purpose, the arithmetic means and the standard deviations of the most frequently measured VOCs and aldehydes in both occupied houses were calculated. As shown in the Table 8, our results are consistent with previous studies: most of the measured VOCs and aldehydes showed concentrations in the range of those measured in other studies. The concentrations of benzene, ethylbenzene, alpha-pinene, and beta-pinene reported here were, however, lower, while the 1,2,4-trimethylbenzene, acrolein, and n-butylacetate concentrations were higher in comparison to previous works.

Table 8 - Concentrations of the most frequent VOCs and aldehydes measured in this study for each occupied house compared with the results of previous studies conducted in newly built, wooden framed, energy-efficient dwellings (n.m.: not measured)

\subsection{Indoor air quality over time: change and causes of variability}

Five main time trends in temporal evolution of IAQ were identified. By comparing our results to those of other longitudinal studies and with the collected informations by questionnaires, the reasons of the observed variability of these concentrations were proposed.

\subsubsection{Stability of aldehyde concentrations}

The concentrations of formaldehyde, hexaldehyde, and benzaldehyde during occupancy were relatively stable over time. 
No seasonal variations were observed for formaldehyde, although higher concentrations have been measured by other authors $[5,23]$ in summer in new buildings. Our results are consistent with previous study [24] where the authors observed that the emission rates of formaldehyde were generally similar at the beginning and the end of the 9.5 month study period in new manufactured houses. Other author [25] demonstrated over the course of 8 months after construction in a new dwelling that formaldehyde showed an initial decay constant similar to that of TVOCs and a later decay three orders of magnitude slower, predicting that formaldehyde emissions would persist for many years. An another study [26] noticed that formaldehyde did not follow the decrease in VOC levels within the initial months after completion but rather continued to decrease slowly over 2 years, especially in new, woodenframed homes. These authors suggested that wooden materials require a longer flushing period than other materials in new homes.

The concentration of hexaldehyde was relatively stable in both occupied houses over time, similar to a previous study [24]. In two of the four newly manufactured houses, the authors reported that the temporal change in the emission rate of hexaldehyde was low over 2 and 9.5 months following installation. In a newly built house, high formaldehyde, pentanal, and hexaldehyde concentrations were ascribed to primary emissions from the plywood subfloor, passage doors, and cabinetry [27]. Other authors found that the most prevalent aldehydes emitted from commonly used building materials, such as particle board and medium-density fibreboard, were hexaldehyde, pentanal, benzaldehyde, and heptanal [28]. Hexaldehyde has also been found to be emitted from wood-based furniture coatings and alkyl paints during the air-drying period $[29,30]$. Recent particle board furniture and wood-pressed products also contributed to the high levels of hexaldehyde and pentanal, but when more than one year old, these materials don't have any influence on both aldehyde levels [31].

\subsubsection{Seasonal variation of $\mathrm{CO}_{2}, \mathrm{PM}_{2.5}$ and acetaldehyde concentrations}


A seasonal variation of concentrations was noticed during occupancy for $\mathrm{CO}_{2}$ (lower level in summer than in winter), and for $\mathrm{PM}_{2.5}$ and acetaldehyde (both presented mean concentrations higher in winter than in summer).

As proposed by others authors [32], the seasonal variation of the $\mathrm{CO}_{2}$ concentration could be related to the increased rate of air exchange in these houses in summer possibly due to the opening of windows. Opening windows produces the greatest increase in air change rates compared to temperature differences and wind effects [33]. The occupants of both houses reported in the questionnaire to open the windows for longer times during the day in summer (more than one half hour per day) than in winter (rarely or never) and used the free night-time cooling in summer.

The seasonal variation of the $\mathrm{PM}_{2.5}$ mass concentration was also previously $[34,35]$ and appears to be partially linked to different ventilation practices in summer and in winter. The highest particulate matter infiltration was observed in summer, and the lowest infiltration was observed in winter [26]. Because of the window opening in summer, the indoor PM concentrations were highly correlated with the outdoor PM concentrations, whereas in winter, the PM concentrations were more strongly influenced by indoor activities. This finding was confirmed in this study, as the indoor and outdoor $\mathrm{PM}_{2.5}$ concentrations showed a strong positive correlation in summer $(\mathrm{r}=0.78)$ and a weak positive correlation in winter $(\mathrm{r}=0.14)$. In winter, the perfect superposition of the $\mathrm{CO}$ concentrations attributable to incomplete combustion processes with the particle number concentrations illustrated for house $\mathrm{B}$ in winter 2009-2011 (Figure 3) indicated the emission of particles from the wood heating system. According to recent studies [37, 38], these emissions of particles occur at the time of lighting the fire or when opening the fire chamber door to put in firewood. 
Figure 3 - Variations in particle number $\left(\right.$ particle $/ \mathrm{cm}^{3}$ ) (grey line) and CO concentration (ppm) (black line) measured every ten minutes in the kitchen/living room of house B during the week of investigation in winter 2010-2011.

The higher level of acetaldehyde observed in winter could be due to the use of a woodburning stove for space heating reported in the questionnaire. This hypothesis is in line with previous studies, which have shown that high emissions of aldehydes, most frequently formaldehyde and acetaldehyde, were induced by conventional wood stoves and fireplaces $[39,40,41,42,43]$.

\subsubsection{Gradual decrease of aliphatic hydrocarbons concentrations}

The gradual decreases in the concentrations of $n$-decane and $n$-undecane to near disappearance observed in this study during occupancy were consistent with the declining time trend over time observed for these compounds by other authors $[5,9,23,25,44]$ but the reasons are not well known.

\subsubsection{Gradual increase of acetic acid concentrations}

The gradual increase in the concentration of the acetic acid over time observed in this study during occupancy was also observed approximately 10 months after the completion of newly manufactured and site-built houses [24], who identified plywood as one of the main possible sources. Acetic acid is known to be emitted from wood-based products [45] and is derived from the degradation of the acetyl groups in hemicellulose [46]. Substantial emissions of acetic acid and/or furfural acid have been observed for heat-treated wood-based building products [47]. According to these authors, the thermal degradation of the hemicelluloses in wood is auto-catalysed by the amounts of acetic acid generated, which could explain the increasing time trend observed for this acid over time. 


\section{ACCEPTED MANUSCRIPT}

\subsubsection{Occasional concentrations peaks for aromatic hydrocarbons, terpenes and other compounds}

During occupancy, the concentrations of all aromatic hydrocarbon compounds (alkylbenzenes, 1,2,4-trimethylbenzene, benzene, ethylbenzene, styrene, toluene and xylenes), all terpenes (alpha-pinene, beta-pinene, camphene, and limonene), acrolein, isovaleraldehyde and $n$-butylacetate were relatively stable over time, except for a few periods of investigation when they increased drastically. These temporary increases in concentration, regardless of the season, seemed to be induced by the occupants' activities affecting the strength of discontinuous indoor sources, which outweighs any influence that the air change rate and the continuous indoor sources could have on the IAQ. During the week of investigation in winter 2009-2010, the simultaneous peaks of xylenes $(\mathrm{m}+p$-xylene and $o$-xylene) with occasional alkylbenzenes and ethylbenzene for both houses were associated with a strong odour of paint sensed by our technical team arriving in each house. Xylenes are widely used in the chemical industry as solvents for products (paints, inks, dyes, adhesives, etc.) and are also emitted by cigarette smoking [48]. According to the questionnaire, touch-up paint was used before the beginning of the sampling period on new wood furniture introduced in house B and during the installation of the wood stove in house E. Cigarette smoking did not seem to be a potential source of xylenes in our case study because. The simultaneous presence of peak concentrations of alpha-pinene and limonene were noticed during the last two weeks of the investigation (summer 2011 and winter 2011-2012) for both houses as well as in winter 20092010 for house B and in summer 2009 for house E. The alpha-pinene concentrations were always higher than those of limonene, except for in house B during summer 2011. Alphapinene is a naturally occurring terpene emitted by wood-based products and is contained in aerosol paint concentrates, cleaning and sanitation products, paints and varnish removers, waterproofing compound solvents, and flavouring [48]. Limonene is also a natural component 
of fruits and vegetables and may also be applied as a flavour and fragrance additive in food, in cleaning or polishing products, and in personal care products or solvents. The installation of new wood-based furniture reported during the weeks of sampling (summer 2009 and summer 2011) by the homeowners of house $E$ reported in the questionnaire could explain the high levels of alpha-pinene and limonene. Others authors [49] noted that after the introduction of new wood-based furniture into a closed room, the indoor concentrations of monoterpenes increased (15 times for alpha-pinene and 4 times for limonene), with much higher concentrations of alpha-pinene. The emissions of limonene were the lowest and decreased with time, while the alpha-pinene emissions increased from the $1^{\text {st }}$ to the $9^{\text {th }}$ days, decreased after 9 days and reached an equilibrium state after the $16^{\text {th }}$ day. The other peak concentrations of terpenes could not be explained by reported activities. As reported previously [8], $n$ butylacetate was quantified at high concentrations of $548 \mu \mathrm{g} / \mathrm{m}^{3}$ in winter $2009-2010$ in house B and of 108 in $\mu \mathrm{g} / \mathrm{m}^{3}$ in the pre-occupancy stage in house E. This compound was related to the daily use of perfume and hairspray in the main bedroom where VOC sampling was carried out in house B and the increase of all pollutants concentrations linked to the switched off MVHR system for house E. After the presentation of these results to the occupants of house B at the beginning of the next period of measurement (summer 2010), they changed their behaviour which impacted the IAQ. Because they decided to use their cosmetics only in the main bathroom separated from their bedroom, the level of this compound decreased sharply and ranged consistently from below the limit of identification to less than $8 \mu \mathrm{g} / \mathrm{m}^{3}$. The questionnaire did not reveal any activity that might explain the peak concentrations of acrolein (winter 2009-2011 for house B), known as a combustion product, or of isovaleraldehyde (summer 2011 for house E).

\subsection{Thermal comfort and causes of the thermal discomfort}


Based on the comparison of the air temperature with two threshold temperature, the underheating was noticed in the heating season in both houses and the overheating in house B during summer. These observations were in accordance with the perceptions of the inhabitants and the reasons of this thermal discomfort were identified. During the heating season, the higher frequency of temperatures under $16^{\circ} \mathrm{C}$ in house $\mathrm{E}$ was explained by the homeowners, who preferred to limit their use of firewood because of the cost. The problems were solved in house B by installing electrical radiators near the dining table in the kitchen/living room. In contrast, overheating was measured in summer in both houses but more frequently in house B. The homeowners of house B did not want to install external solar shading simply for aesthetics and for architectural reasons, while house E was equipped with external solar shading. The presence of overheating just during the first summer of occupancy in house E seemed to show that the occupants learned to manage their external solar shading effectively during the following summers. Our results were in accordance with those in eight passive houses [20].

\section{Conclusions}

Two newly built, wooden-framed, energy-efficient houses were investigated from 2009 to 2012 in order to follow up on the IAQ and occupant comfort over time. The investigation periods started from the completion of houses construction before occupancy and finished after three years of occupancy. Despite the limited sample size, this study brings new data on IEQ in energy-efficient and airtight buildings, as well as on temporal variations of indoor air concentrations that were never described before in such buildings over a long period.

According to our measurements and observations, the IEQ and comfort conditions in these both houses were generally acceptable over time despite some specific problems. Regarding IAQ, the comparison with literature data did not show any specificity regarding measured 
indoor air pollutants in these buildings. The change of indoor concentrations over time appeared to be consistent with previous observations. The use of low emitting construction, and decoration products, furniture and consumer products would limit the episodic indoor air pollution events linked to human activities. Because of the ventilation systems play a crucial role in providing a sufficient air renewal rate to maintain good IAQ especially in buildings with high airtightness, it would be useful to improve the performance and ventilation system's robustness with more quiet, user-friendly and operational effectiveness of ventilation systems all lifelong in order to avoid the risks of occupants turning them off. In addition, mandatory inspection of these systems by a qualified professional as well as frequent maintenance would increase the chance of achieving the designed exhaust air flow rate and maintaining proper ventilation conditions during occupancy. Thermal discomfort must be avoided by bringing more attention from the beginning of the design phase and in informing the occupants of their behaviour's impact especially in these buildings where heating and cooling energy use are reduced.

For the future, it would be particularly interesting to investigate other energy-efficient houses occupied by different households in order to study the user behaviour with regard to the IEQ and energy consumption of a house. The comparison of occupant's behaviour could be made between owners/tenants, high income/low income, more or less ecofriendly people, more or less motivated people by IAQ, etc. It would also be interesting to study the IEQ in retrofitted energy-efficient buildings. The study could be extended to other types of buildings with specific occupation rate and indoor pollution sources, e.g., multi-family dwellings, schools, and offices.

\section{Acknowledgements}


This study was carried out by the CSTB in the frame of the French OQAI, funded by the Ministries in charge of Housing, Environment and Health, the Environment and Energy Management Agency (ADEME), the French Agency for Food, Environmental and Occupational Health Safety (ANSES), and the CSTB. The authors thank the owners of the both houses for their time and for opening their homes. Sample analyses were conducted by two laboratories (Laboratoire d'Hygiène de la Ville de Paris, and CSTB laboratory).

\section{References}

[1] JORF (2009). Loi n 2009-967 du 3 août 2009 de programmation relative à la mise en œuvre du Grenelle de l'environnement (1). Journal Officiel de la République Française ${ }^{\circ} 179$ du 5 août 2009, p 13031.

[2] JORF (2010). Arrêté du 26 octobre 2010 relatif aux caractéristiques thermiques et aux exigences de performance énergétique des bâtiments nouveaux et des parties nouvelles de bâtiments. Journal Officiel de la République Française N²50 du 27 octobre 2010, pp.19260.

[3] Crump DR, Dengel A, Swainson M. Indoor air quality in highly energy efficient homes a review. NHBC Foundation report NF18, Published by IHS BRE Press on behalf of the NHBC Foundation, ISBN: 978-1-84806-104-0; 2009.

[4] Yu CWF, Kim JT. Low-carbon housings and Indoor air quality. Indoor Built Environ 2012;21:5-15.

[5] Crump DR, Squire RW, Yu CWF. Sources and concentrations of formaldehyde and other volatile organic compounds in the indoor air of four newly built unoccupied test houses, Indoor Built Environ 1997;6:45-55.

[6] Teichman K, Emmerich S, Persily A. Indoor air quality in high-performing building case studies : a wealth of intent, a dearth of data. ASHRAE's High Performing Buildings magazine 2013;6:34-43. 
[7] Wargocki P, Sherman M, de Gids W, Wouters P, Allard F, Carrié R et al. Proposed Research Agenda for Achieving Indoor Air Quality Supporting Health and Comfort in Highly Energy Efficient Buildings, Report 2013.

[8] Derbez M, Berthineau B, Cochet V, Lethrosne M, Pignon C, Ribéron J et al.(2014) Indoor air quality and comfort in seven newly built, energy-efficient houses in France. Build Environ 2014;72:173-87.

[9] Dalang F, Bianco MA. Pour un air sain dans des bâtiments durables, Pollution intérieure dans trois maisons familiales, étude pilote pour la surveillance de la qualité de l'air dans des habitations. Rapport Service cantonal de toxicologie industrielle et de protection contre les pollutions intérieures; 2006.

[10] Dengel A, Swainson M. Assessment of MVHR systems and air quality in zero carbon homes. NHBC Foundation report NF52, Published by IHS BRE Press on behalf of the NHBC Foundation, ISBN: 978-1-85806-340-2; 2013.

[11] Engelmann P, Roth K, Tiefenbeck V. Comfort, indoor air quality, and energy consumption in low energy homes, NREL Report No. SR-5500-56023; DOE/GO-102013$3746 ; 2013$.

[12] Patko C, Patko I, Pasztory Z. Indoor air quality testing in low-energy wooden houses : measurement of formaldehyde and VOC-s. Acta Polytech Hun;2013:10,105-16.

[13] Derbez M, Berthineau B, Cochet V, Lethrosne M, Pignon C, Ribéron J et al. Méthodologie d'évaluation de la qualité de l'air intérieur, du confort des occupants et des consommations énergétiques réelles des bâtiments d'habitation performants en énergie. Environ Risque Sante 2012;11:40-51.

[14] Kirchner S, Derbez M, Duboudin C, Elias P, Gregoire A, Lucas JP et al. Indoor air quality in French dwellings. In: Proceedings of Indoor Air Quality 2008, Paper ID: 574. 
[15] Ramalho O, Derbez M, Grégoire A, Garrigue J, Kirchner S. French permanent survey on Indoor Air Quality - Part. 1 : Measurement protocols and quality control. In : Proceedings of Healthy Buildings 2006, vol 3, pp. 321-6.

[16] Derbez M, Grégoire A, Ramalho O, Garrigue J, Kirchner S. French permanent survey on Indoor Air Quality: Part. 2: Questionnaires and validation procedure of collected data. In : Proceedings of Healthy Buildings 2006, vol 3, pp. 327-332.

[17] van Dijken F, Balvers JR, Boestra AC. The quality of mechanical systems in newly built Dutch dwellings. In : Proceedings of Indoor Air 2011, Manuscript: a372_5.

[18] Balvers J, Bogers R, Jongeneel R, van Kamp I, Boerstra A, van Dijken F. Mechanical ventilation in recently built Dutch homes: technical shortcomings, possibilities for improvement, perceived indoor, environment and health effects. Archit Sci Rev 2012;55:4-14. [19] ZCH. Mechanical ventilation with heat recovery in new homes. Final report. Ventilation and Indoor Air Quality Task Group. Zero Carbon Hub, Milton Keynes; 2013.

[20] Larsen TS, Jensen RL, Daniels O. The comfort houses - Measurements and analysis of the indoor environment and energy consumption in 8 passive houses 2008-2011. DCE technical report N 145, Aalborg University, ISSN 1901-726X; 2012.

[21] Knudsen HN, Jensen OM, Kristensen L. Occupant satisfaction with new low-energy houses. In : Proceedings of Healthy Buildings 2012, paper 2E.2.

[22] Fischer A, Langer S, Evert Ljungström E. Chemistry and indoor air quality in a multistorey wooden passive (low energy) building: Formation of peroxyacetyl nitrate. Indoor Built Environ 2014;23:485-96.

[23] Järnström H, Saarela K, Kalliokoski P, Pasanen AL. Reference values for indoor air pollutant concentrations in new, residential buildings in Finland. Atmos environ 2006;40:7178-91. 
[24] Hodgson AT, Rudd AF, Beal D, Chandra S. Volatile organic compound concentrations and emission rates in new manufactured and site-built houses. Indoor Air 2000;10:178-92.

[25] Brown SK. Volatile organic pollutants in new and established buildings in Melbourne, Australia, Indoor Air 2002;12:55-63.

[26] Park JS, Ikeda K. Variations of formaldehyde and VOC levels during 3 years in new and older homes. Indoor Air 2006;16:129-35.

[27] Hodgson AT, Beal D, Mcllvaine JER. Sources of formaldehyde, other aldehydes and terpenes in a new manufactured house. Indoor Air 2002;12:235-42.

[28] Baumann MGD, Lorenz LE, Batterman SA, Zhang GZ. Aldehyde emissions from particleboard and medium density fiberboard products. Forest Prod J 2000;50:75-82.

[29] Chang JCS, Guo Z. Emissions of odorous aldehydes from alkyd paint. Atmos environ 1998;32:3581-6.

[30] Fortmann R, Roache N, Chang JCS, Guo Z. Characterization of emissions of volatile organic compounds from interior alkyd paint. Japca J Air Waste Ma 1998;48:931-40.

[31] Dassonville C, Demattei C, Laurent AM, Le Moullec Y, Seta N, Momas I. Assessment and predictor determination of indoor aldehyde levels in Paris newborn babies' homes. Indoor Air 2009;19:314-23.

[32] Wallace L, Emmerich SJ, Howard-Reed C. Continuous measurements of air change rates in an occupied house for 1 year : the effect of temperature, wind, fans, and windows, J Expo Sci Environ Epidemiol 2002;12:296-306.

[33] Howard-Reed C, Wallace LA, Ott WR. The effect of opening windows on air change rates in two homes. Japca J Air Waste Ma 2002;52:147-59.

[34] Fromme H, Twardella D, Dietrich S, Heitmann D, Schierl R, Liebl B. et al. Particulate matter in the indoor air of classrooms-exploratory results from Munich and surrounding area. Atmos environ 2007;41:854-66. 
[35] Keeler GJ, Dvonch T, Yip FY, Parker EA, Israel BA, Marsik FJ et al. Assessment of personal and community-level exposure to particulate matter among children with asthma in Detroit, Michigan, as part of Community Action Against Asthma (CAAA). Environ Health Persp 2002;110 (Suppl. 2):173-81.

[36] Hänninen O, Hoek G, Mallone S, Chellini E, Katsouyanni K, Gariazzo C et al. Seasonal patterns of outdoor PM infiltration into indoor environments: review and meta-analysis of available studies from different climatological zones in Europe. Air Qual Atmos Health $2011 ; 4: 221-33$

[37] Carvalho RL, Jensen OM, Afshari A, Bergsøe NC. Wood-burning stoves in low-carbon dwellings, Energ Buildings 2013;59:244-51.

[38] Salthammer T, Schripp T, Wientzek S, Wensing M. Impact of operating wood-burning fireplace ovens on indoor air quality, Chemosphere 2014;103:205-11.

[39] McDonald JD, Zielinska B, Fujita EM, Sagebiel JC, Chow JC, Watson JG. Fine particle and gaseous emission rates from residential wood combustion. Environ Sci Technol 2000;34:2080-91.

[40] Schauer JJ, Kleeman MJ, Cass GR, Simoneit BRT. Measurement of emissions from air pollution sources. 5. C1-C32 organic compounds from gasoline powered motor vehicles. Environ Sci Technol 2002;36:1169-80.

[41] Hedberg E, Kristensson A, Ohlsson M, Johansson C, Johansson PA, Swietlicki E. et al. Chemical and physical characterization of emissions from birch wood combustion in a wood stove. Atmos environ 2002;36:4823-37.

[42] Gustafson P, Barregard L, Strandberg B, Sällsten G. The impact of domestic wood burning on personal, indoor and outdoor levels of 1,3-butadiene, benzene, formaldehyde and acetaldehyde. J Environ Monitor 2007;9:23-32. 
[43] Cerqueira M, Gomes L, Tarelho L, Pio C. Formaldehyde and acetaldehyde emissions from residential wood combustion in Portugal, Atmos environ 2013;72:171-6.

[44] Yamaguchi T, Nakajima D, Ezoe Y, Fujimaki H, Shimada Y, Kozawa K et al. Measurement of volatile organic compounds (VOCs) in new residential buildings and VOCs behavior over time, J UOEH 2006;28(1):13-27.

[45] Hodgson AT, Levin H. Volatil organic compounds in indoor air : a review of concentrations measured in North America since 1990. Report $N^{\circ}$ LBNL-51715, Laurence Berkeley National Laboratory, Berkeley, CA; 2003.

[46] Colak S, Colakoglu G. Volatile acetic acid and formaldehyde emission from plywood treated with boron compound, Build Environ 2004;39:533-6.

[47] Uhde E, Salthammer T. Impact of reaction products from building materials and furnishings on indoor air quality - A review of recent advances in indoor chemistry, Atmos environ 2007;41:3111-28.

[48] Sarigiannis DA, Karakitsios SP, Gotti A, Liakos IL, Katsoyiannis A. Exposure to major volatile organic compounds and carbonyls in European indoor environments and associated health risk, Environ Int 2011;37:743-65.

[49] Marć M, Namieśnik J, Zabiegała B. Small-scale passive emission chamber for screening studies on monoterpene emission flux from the surface of wood-based indoor elements, Sci Total Environ 2014;481:35-46. 
Table 1 - Main characteristics, occupation description of both single-family detached houses (n.e.: not estimated)

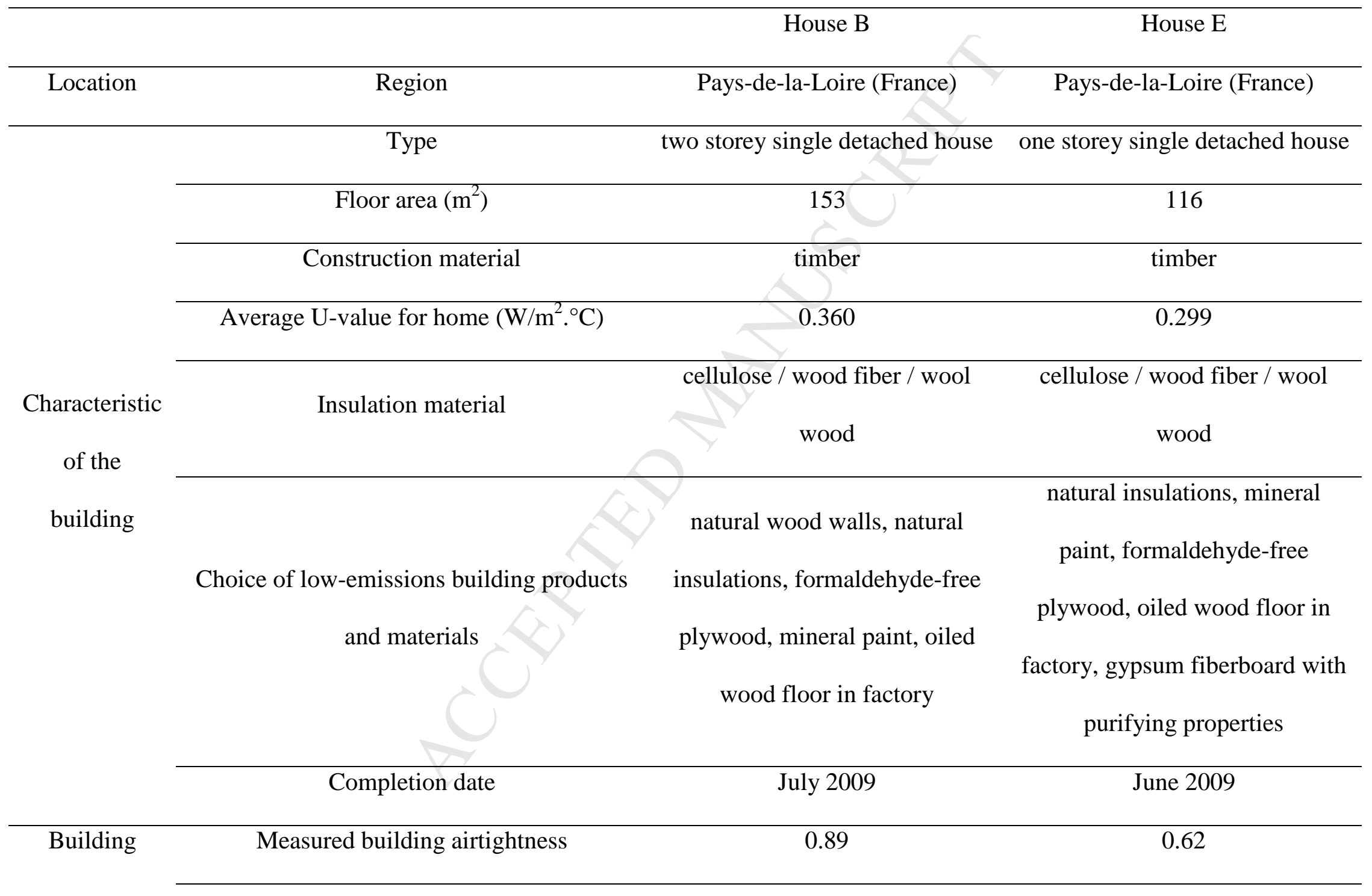




\begin{tabular}{|c|c|c|c|}
\hline $\begin{array}{l}\text { airtightness } \\
\text { and energy }\end{array}$ & $\begin{array}{l}\text { (ACH at } 50 \text { pascals pressure) } \\
{\left[\mathrm{m}^{3} / \mathrm{h} \cdot \mathrm{m}^{2} \text { at } 4 \text { pascals pressure }\right]}\end{array}$ & [0.19] & {$[0.11]$} \\
\hline performance & $\begin{array}{l}\text { Annual consumption of conventional } \\
\text { primary energy }{ }^{\mathrm{a}}\left(\mathrm{kWh} / \mathrm{m}^{2} / \text { year }\right)\end{array}$ & 46 & 79 \\
\hline & Energy-Efficient building certification & BBC-Effinergie (on going) & in accordance with Passivhaus \\
\hline \multirow[t]{2}{*}{ Equipments } & Ventilation system & $\begin{array}{l}\text { Balanced MVHR }{ }^{\mathrm{b}} \text { with } 3 \text { fan } \\
\text { speeds (low /medium /high) } \\
\text { Heat recovery rate : } 97-99 \% \\
\text { Intake air cleaned by a G4 filter } \\
\text { (or F8 filter) } \\
\text { Extract side protected by a G4 } \\
\text { filter }\end{array}$ & $\begin{array}{l}\text { Balanced MVHR }{ }^{\mathrm{b}} \text { with } 3 \text { fan } \\
\text { speeds (low /medium/high) } \\
\text { Heat recovery rate : } 97-99 \% \\
\text { Intake air cleaned by a G4 filter } \\
\text { (or F8 filter) } \\
\text { Extract side protected by a G4 } \\
\text { filter }\end{array}$ \\
\hline & $\begin{array}{l}\text { Averaged air exchange rate }{ }^{c}(\mathrm{ACH}) \text { per } \\
\text { house according the fan speed of MVHR } \\
\text { system [8] }\end{array}$ & $\begin{array}{c}<0.05 \text { (switched off) } \\
0.3 \text { (low) } \\
0.5 \text { (medium) } \\
\text { n.e. (high) }\end{array}$ & $\begin{array}{c}<0.05 \text { (switched off) } \\
0.1 \text { (low) } \\
0.4 \text { (medium) } \\
0.2 \text { (high) }\end{array}$ \\
\hline
\end{tabular}




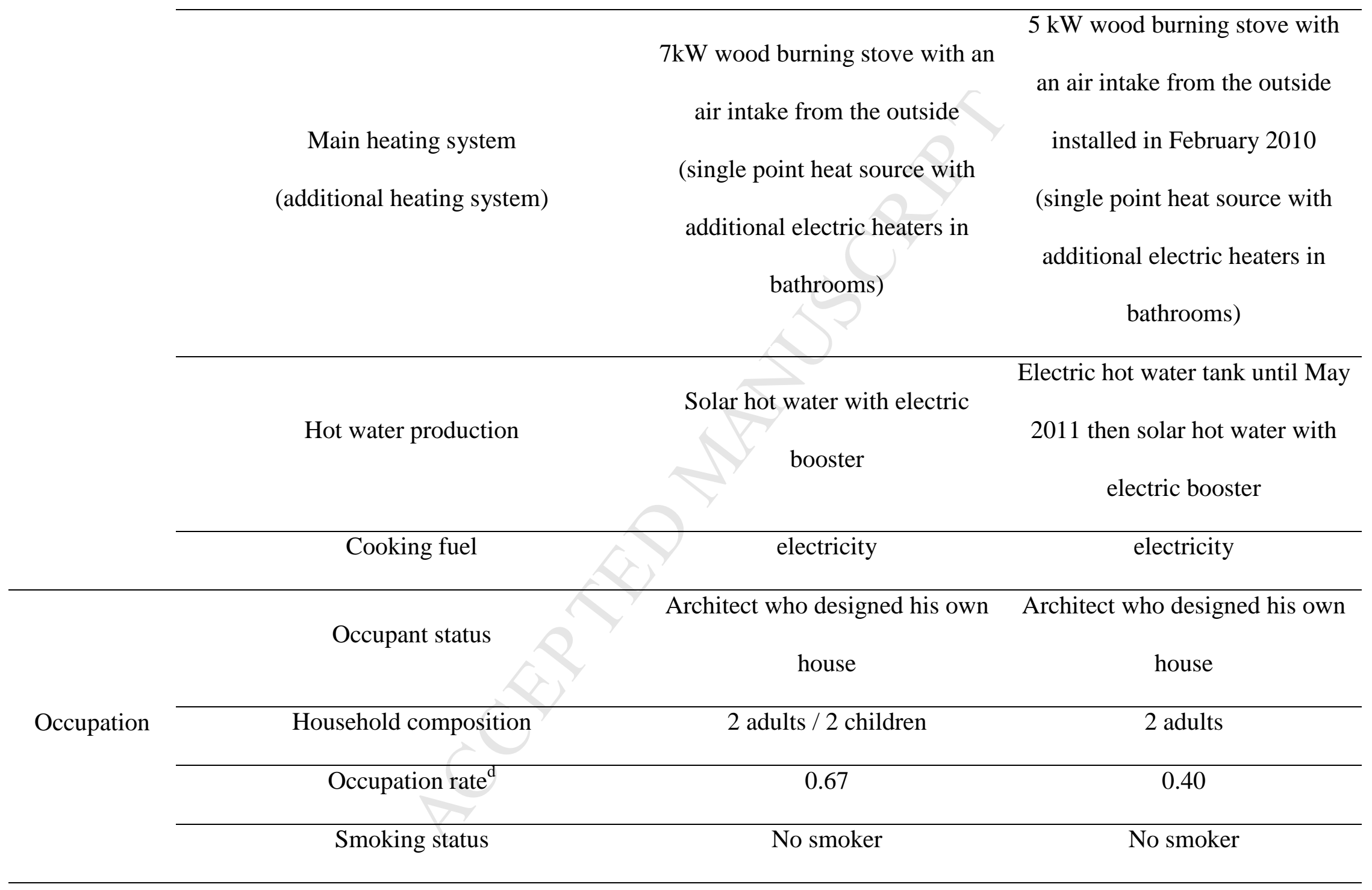


annual consumption of conventional primary energy for heating, cooling, ventilation, auxiliaries, domestic hot water production and lighting facilities according to the French thermal regulation RT $2005\left(\mathrm{kWh} / \mathrm{m}^{2} /\right.$ year). The primary energy conversion factors were 0.6 for wood and 2.58 for electricity.

${ }^{\mathrm{b}}$ mechanical ventilation with heat recovery

${ }^{c}$ averaged air exchange rate derived from the $\mathrm{ACH}$ measurements by SF6 tracer gas in two rooms of each house in taking into account the volume of those rooms and the total volume of the house

$\mathrm{d}$ occupation rate $=$ number of occupants $/$ number of main rooms 
Table 2 - Weekly mean outdoor temperature $\left({ }^{\circ} \mathrm{C}\right) \pm$ standard deviation, moving dates and weekly investigation dates of the IAQ and thermal comfort parameters in the pre-occupancy stage and in the occupancy stage of both houses (n.m.:not measured)

\begin{tabular}{|c|c|c|}
\hline & House B & House E \\
\hline Pre-occupancy & $\begin{array}{l}\text { July, 15th-22nd , } 2009 \\
\text { (outdoor temperature : n.m.) }\end{array}$ & $\begin{array}{l}\text { June, 22nd-29th, } 2009 \\
\text { (outdoor temperature : n.m.) }\end{array}$ \\
\hline Move in date & July, 2009 & August, 2009 \\
\hline Summer 2009 & $\begin{array}{l}\text { August 25th-September 1st, } 2009 \\
\text { (outdoor temperature : n.m.) }\end{array}$ & $\begin{array}{l}\text { August 26th-September 2nd, } 2009 \\
\text { (outdoor temperature : n.m.) }\end{array}$ \\
\hline Winter 2009-2010 & $\begin{array}{l}\text { February, 12th-19th, } 2010 \\
\text { (outdoor temperature : } 2.4 \pm 3.5 \text { ) }\end{array}$ & $\begin{array}{l}\text { February, 12th-19th, } 2010 \\
\text { (outdoor temperature : } 2.1 \pm 3.3 \text { ) }\end{array}$ \\
\hline Summer 2010 & $\begin{array}{l}\text { August } 31 \text { st-September, } 7 \text { th, } 2010 \\
\text { (outdoor temperature : } 19.9 \pm 5.1 \text { ) }\end{array}$ & $\begin{array}{c}\text { September, 1st-8th, } 2010 \\
\text { (outdoor temperature : } 19.5 \pm 4.8 \text { ) }\end{array}$ \\
\hline Winter 2010-2011 & $\begin{array}{l}\text { January, 25th-February } 1 \text { st, } 2011 \\
\text { (outdoor temperature : } 2.7 \pm 2.9 \text { ) }\end{array}$ & $\begin{array}{l}\text { January, 26th-february } 2^{\text {nd }}, 2011 \\
\text { (outdoor temperature : } 1.7 \pm 2.9 \text { ) }\end{array}$ \\
\hline Summer 2011 & $\begin{array}{c}\text { September, } 1 \text { st-8th, } 2011 \\
\text { (outdoor temperature : } 18.9 \pm 3.7 \text { ) }\end{array}$ & $\begin{array}{c}\text { September, } 2^{\text {nd }}-9 \text { th, } 2011 \\
\text { (outdoor temperature : } 18.8 \pm 3.8 \text { ) }\end{array}$ \\
\hline Winter 2011-2012 & $\begin{array}{l}\text { January, 3rd-10th, } 2012 \\
\text { (outdoor temperature : } 10.1 \pm 1.5 \text { ) }\end{array}$ & $\begin{array}{c}\text { January, } 2^{\text {nd }}-9 \text { th, } 2012 \\
\text { (outdoor temperature }: 9.2 \pm 1.9 \text { ) }\end{array}$ \\
\hline
\end{tabular}




\section{ACCEPTED MANUSCRIPT}

Table 3. Measured air exhaust rate $(1 / \mathrm{s})$ per room as a function of the fan speed of the MVHR system and comparison to the designed air exhaust rate for the medium fan speed for both houses (n.m.: not measured)

\begin{tabular}{|c|c|c|c|c|c|c|c|c|c|}
\hline \multirow[b]{2}{*}{ Rooms } & \multirow[b]{2}{*}{$\begin{array}{c}\text { Fan } \\
\text { speed } \\
\text { of } \\
\text { MVHR }\end{array}$} & \multicolumn{4}{|c|}{ House B } & \multicolumn{4}{|c|}{ House E } \\
\hline & & $\begin{array}{c}\text { Pre- } \\
\text { occupancy }\end{array}$ & $\begin{array}{c}\text { Winter } \\
2010-2011\end{array}$ & $\begin{array}{c}\text { Winter } \\
2011- \\
2012\end{array}$ & $\begin{array}{c}\text { Designed } \\
\text { air } \\
\text { exhaust } \\
\text { rate }\end{array}$ & $\begin{array}{c}\text { Pre- } \\
\text { occupancy* }\end{array}$ & $\begin{array}{c}\text { Winter } \\
2010- \\
2011\end{array}$ & $\begin{array}{c}\text { Winter } \\
2011- \\
2012\end{array}$ & $\begin{array}{c}\text { Designed } \\
\text { air } \\
\text { exhaust } \\
\text { rate }\end{array}$ \\
\hline \multirow{3}{*}{$1^{\text {st }}$ bathroom } & low & $3 \pm 1$ & $2 \pm 1$ & $<2$ & & $2 \pm 1$ & $<2$ & $3 \pm 1$ & \multirow{3}{*}{$8 \pm 1$} \\
\hline & medium & $6 \pm 1$ & $6 \pm 1$ & $5 \pm 1$ & $6 \pm 1$ & $4 \pm 1$ & $4 \pm 1$ & $5 \pm 1$ & \\
\hline & high & $7 \pm 1$ & $8 \pm 1$ & $6 \pm 1$ & & $7 \pm 1$ & $7 \pm 1$ & $8 \pm 1$ & \\
\hline \multirow{3}{*}{$2^{\text {nd }}$ bathroom } & low & $5 \pm 1$ & $<2$ & $5 \pm 1$ & & $2 \pm 1$ & $<2$ & $3 \pm 1$ & \multirow{3}{*}{$8 \pm 1$} \\
\hline & medium & $11 \pm 1$ & $3 \pm 1$ & $10 \pm 1$ & $11 \pm 1$ & $4 \pm 1$ & $4 \pm 1$ & $4 \pm 1$ & \\
\hline & high & $13 \pm 1$ & $4 \pm 1$ & + & & $7 \pm 1$ & $7 \pm 1$ & $7 \pm 1$ & \\
\hline \multirow{3}{*}{$\begin{array}{l}\text { kitchen/living } \\
\text { room }\end{array}$} & low & n.m. & $<2 / 5^{\circ} \pm 1$ & -1 & & n.m. & $4 \pm 1$ & $4 \pm 1$ & \multirow{3}{*}{$14 \pm 1$} \\
\hline & medium & n.m. & $\begin{array}{l}4 \pm 1 / \\
12 \cdot+1\end{array}$ & $8 \pm 1$ & $14 \pm 1$ & n.m. & $8 \pm 1$ & $8 \pm 1$ & \\
\hline & high & n.m. & $\begin{array}{l}6 \pm 1 / \\
14^{\bullet} \pm 1\end{array}$ & $0 \pm 1$ & & n.m. & $13 \pm 1$ & $16 \pm 1$ & \\
\hline
\end{tabular}

* measured before the MVHR system's adjustment

- second measurement after the extract filter's cleaning 
Table 4 - Measured continuous A-weighted sound pressure level or LAeq ( $\mathrm{dB}(\mathrm{A}))$ between 50 and $1000 \mathrm{~Hz}$ per room as a function of the fan speed of the MVHR system for both houses during winter 2011-2012 (n.m.: not measured)

\begin{tabular}{ccccccc}
\hline & \multicolumn{3}{c}{ House B } & \multicolumn{3}{c}{ House E } \\
\cline { 2 - 6 } Rooms & \multicolumn{5}{c}{ Fan speed of MVHR } \\
& Low & Medium & High & Low & Medium & High \\
\hline kitchen/living room & 27 & 29 & 44 & 24 & 25 & 27 \\
$1^{\text {st }}$ bedroom & 29 & 32 & 37 & 18 & 25 & 27 \\
$2^{\text {nd }}$ bedroom & 23 & 32 & 39 & 21 & 25 & 25 \\
$3^{\text {rd }}$ bedroom & 19 & 31 & 38 & - & - & - \\
$1^{\text {st }}$ bathroom & 27 & 25 & 33 & 17 & 17 & 20 \\
$2^{\text {nd }}$ bathroom & 27 & 34 & 43 & 21 & 21 & 28 \\
office & 25 & n.m. & 29 & 18 & 18 & 20 \\
utility room & 20 & 48 & 56 & 24 & 31 & 50 \\
\hline
\end{tabular}


Table 5 - Indoor TVOC, VOC and aldehyde levels ( $\mu \mathrm{g} / \mathrm{m} 3)$ measured weekly in the main bedroom of each house at the pre-occupancy stage and during occupancy by season. LOD: limit of detection; LOI: limit of identification ( $<1 \mu \mathrm{g} / \mathrm{m} 3)$; LOQ: limit of quantification; n.a.: not available

\begin{tabular}{|c|c|c|c|c|c|c|c|c|c|c|c|c|c|c|c|c|}
\hline \multirow[b]{2}{*}{$\begin{array}{l}\text { Chemical } \\
\text { class }\end{array}$} & \multirow[b]{2}{*}{ Compounds } & \multirow[b]{2}{*}{$\begin{array}{l}\text { Quantification } \\
\text { frequency }(\%)\end{array}$} & \multicolumn{7}{|c|}{ House B } & \multicolumn{7}{|c|}{ House E } \\
\hline & & & 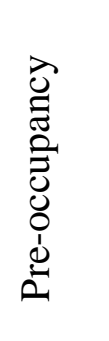 & 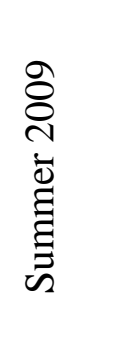 & 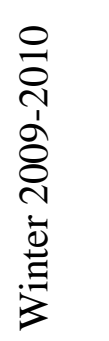 & 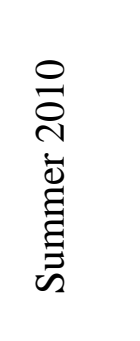 & 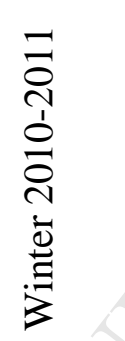 & 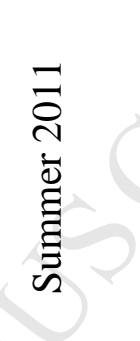 & 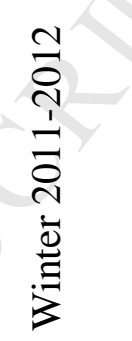 & 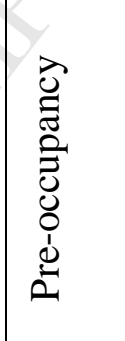 & 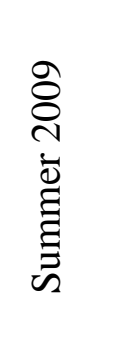 & 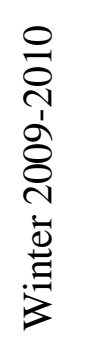 & 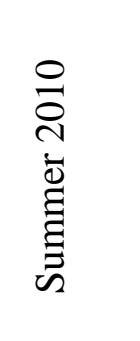 & 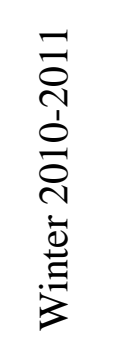 & $\begin{array}{l}\bar{\Xi} \\
\bar{N} \\
\bar{\Xi} \\
\Xi \\
\Xi \\
\bar{\Xi}\end{array}$ & 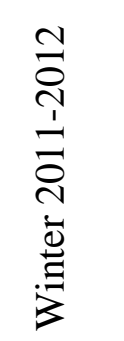 \\
\hline \multicolumn{2}{|c|}{ TVOC $^{\mathrm{a}}$} & & 15 & 6 & 128 & $<\mathrm{LOI}$ & $<\mathrm{LOI}$ & 84 & 381 & 3087 & 17 & 569 & 17 & 6 & 82 & 228 \\
\hline \multirow{8}{*}{$\begin{array}{c}\text { Aromatic } \\
\text { hydrocarbons }\end{array}$} & Alkylbenzenes $^{b}$ & 79 & 19.0 & $<\mathrm{LOI}$ & 9.8 & $<\mathrm{LOI}$ & 9.8 & 7.5 & 5.1 & 92.1 & $<\mathrm{LOI}$ & 28.0 & 10.4 & 9.1 & 10.0 & 8.5 \\
\hline & $\begin{array}{c}1,2,4- \\
\text { trimethylbenzene }^{\mathrm{c}}\end{array}$ & 100 & 5.4 & 4.7 & 4.7 & 1.7 & 3.0 & 6.5 & 4.5 & 1.4 & 7.8 & 7.9 & 3.5 & 2.1 & 1.3 & 5.0 \\
\hline & Benzene $^{c}$ & 64 & 1.0 & 1.2 & 1.8 & $<$ LOQ & 3.7 & 2.3 & n.a & 1.0 & $<\mathrm{LOQ}$ & 1.8 & $<$ LOQ & 1.4 & 3.4 & $<\mathrm{LOD}$ \\
\hline & Ethylbenzene $^{\mathrm{c}}$ & 93 & 3.6 & 1.7 & 13.2 & $<\mathrm{LOQ}$ & 1.8 & 2.1 & 2.6 & 222.4 & 5.1 & 6.8 & 1.8 & 1.3 & 6.3 & 3.7 \\
\hline & Styrene $^{c}$ & 86 & 5.0 & 1.8 & 4.0 & 1.7 & 2.6 & 4.5 & 4.4 & 7.2 & 0.2 & 0.8 & $<$ LOQ & $<\mathrm{LOQ}$ & 2.1 & 1.9 \\
\hline & Toluene $^{c}$ & 100 & 11.0 & 5.4 & 6.2 & 2.6 & 4.4 & 9.0 & 8.8 & 36.7 & 5.1 & 5.3 & 3.0 & 2.9 & 15.9 & 7.1 \\
\hline & $\mathrm{m}+\mathrm{p}-$ Xylene $\mathrm{c}^{\mathrm{c}}$ & 100 & 10.7 & 3.7 & 38.4 & 2.5 & 4.8 & 3.0 & 3.8 & 569.3 & $<\mathrm{LOQ}$ & 22.0 & 4.5 & 4.4 & 12.3 & 6.4 \\
\hline & o-Xylene ${ }^{c}$ & 71 & 5.4 & 2.0 & 13.4 & 1.6 & 2.0 & $<\mathrm{LOQ}$ & $<\mathrm{LOQ}$ & 163.6 & 5.4 & 8.4 & n.a & n.a & 4.8 & 2.1 \\
\hline
\end{tabular}




\begin{tabular}{|c|c|c|c|c|c|c|c|c|c|c|c|c|c|c|c|c|}
\hline \multirow{2}{*}{$\begin{array}{c}\text { Aliphalic } \\
\text { hydrocarbons }\end{array}$} & n-Decane ${ }^{c}$ & 71 & 24.1 & 16.0 & 3.4 & $<\mathrm{LOQ}$ & $<\mathrm{LOQ}$ & 1.9 & 1.1 & 101.8 & 14.0 & 6.5 & $<\mathrm{LD}$ & 1.5 & $<\mathrm{LOD}$ & 2.9 \\
\hline & n-Undecane ${ }^{c}$ & 57 & 37.9 & 24.0 & 3.4 & $<\mathrm{LOQ}$ & 5.1 & $<\mathrm{LOD}$ & $<\mathrm{LOD}$ & 93.4 & 26.0 & 5.7 & $<\mathrm{LOD}$ & $<\mathrm{LOQ}$ & $<\mathrm{LOQ}$ & 3.1 \\
\hline \multirow{6}{*}{ Aldehydes } & Acetaldéhyde $^{c}$ & 100 & 16.1 & 7.9 & 22.1 & 8.6 & 29.7 & 10.0 & 16.1 & 30.8 & 23.0 & 29.0 & 18.3 & 23.3 & 16.6 & 55.3 \\
\hline & Acrolein $^{c}$ & 100 & 2.8 & 0.9 & 2.4 & 5.3 & 18.3 & 1.2 & 2.2 & 3.1 & 1.6 & 2.9 & 2.6 & 1.6 & 2.4 & 3.0 \\
\hline & Benzaldehyde $^{a}$ & 86 & 3.6 & $<\mathrm{LOI}$ & 5.4 & 2.0 & 2.2 & 4.0 & 3.4 & 23.6 & $<\mathrm{LOI}$ & 2.0 & 2.9 & 1.8 & 10.2 & 7.3 \\
\hline & Formaldehyde $^{c}$ & 100 & 48.3 & 20.0 & 31.1 & 25.0 & 35.4 & 28.5 & 26.8 & 21.7 & 17.0 & 20.0 & 24.5 & 14.4 & 29.8 & 19.0 \\
\hline & Hexaldehyde $^{c}$ & 100 & 112.0 & 29.0 & 36.1 & 41.8 & 67.3 & 45.7 & 63.9 & 684.9 & 96.0 & 88.0 & 121.5 & 53.9 & 125.4 & 111.7 \\
\hline & Isovaleraldehyde $^{b}$ & 57 & 6.0 & $<\mathrm{LOI}$ & $<$ LOI & 2.8 & $<\mathrm{LOI}$ & $<\mathrm{LOI}$ & $<\mathrm{LOI}$ & 13.1 & 7.3 & 5.0 & 5.1 & 1.6 & 22.0 & $<\mathrm{LOI}$ \\
\hline \multirow{4}{*}{ Terpenes } & Alpha-pinene $^{b}$ & 100 & 43.2 & 13.0 & 9.0 & 9.6 & 11.0 & 19.5 & 24.2 & 294.4 & 18.0 & 6.8 & 8.6 & 5.9 & 23.8 & 25.0 \\
\hline & Beta-pinene $^{b}$ & 57 & 6.8 & $<\mathrm{LOI}$ & $<\mathrm{LOI}$ & 2.1 & 2.2 & 5.6 & 3.9 & n.a & $<\mathrm{LOI}$ & $<\mathrm{LOI}$ & 2.6 & $<\mathrm{LOI}$ & 5.5 & 7.4 \\
\hline & Camphene $^{\mathrm{b}}$ & 79 & 8.2 & $<\mathrm{LOI}$ & 2.6 & 2.1 & 3.3 & $<\mathrm{LOI}$ & 3.4 & 23.7 & $<\mathrm{LOI}$ & 3.2 & 2.4 & 2.2 & 4.7 & 4.3 \\
\hline & Limonene $^{\mathrm{b}}$ & 100 & 18.3 & 6.6 & 4.7 & 4.7 & 7.2 & 51.8 & 18.6 & 92.3 & 11.0 & 9.2 & 5.9 & 6.2 & 15.7 & 22.6 \\
\hline Esters & n-butylacetate ${ }^{b}$ & 64 & 6.5 & $<\mathrm{LOI}$ & 548.0 & 4.3 & $<\mathrm{LOI}$ & 7.1 & $<$ LOI & 108.2 & $<\mathrm{LOI}$ & 2.5 & 3.5 & 1.9 & $<$ LOI & 8.7 \\
\hline Acide & Acetic acid ${ }^{b}$ & 64 & $<\mathrm{LOI}$ & $<\mathrm{LOI}$ & 3.2 & 3.9 & 9.6 & 22.3 & 45.0 & $<$ LOI & $<$ LOI & 5.4 & $<\mathrm{LOI}$ & 4.4 & 48.0 & 25.2 \\
\hline
\end{tabular}

\footnotetext{
${ }^{\text {a }}$ median concentration of TVOC measured by PID

${ }^{\mathrm{b}}$ calibrated as toluene equivalent
} 
${ }^{c}$ calibrated as specific calibration 
Table 6 - Weekly PM2.5 mass concentration $(\mu \mathrm{g} / \mathrm{m} 3)$ and median number of particles (particle/cm3) measured in the kitchen/living room at each house at the pre-occupancy stage and during occupancy by season. (n.a.: not available)

\begin{tabular}{|c|c|c|c|c|}
\hline & \multicolumn{2}{|r|}{ House B } & \multicolumn{2}{|r|}{ House E } \\
\hline & $\begin{array}{c}\mathrm{PM}_{2.5} \text { mass } \\
\text { concentration } \\
\left(\mu \mathrm{g} / \mathrm{m}^{3}\right)\end{array}$ & $\begin{array}{c}\text { Median value of particle } \\
\text { number }[0.3-20] \\
\left(\text { particle } / \mathrm{cm}^{3}\right)\end{array}$ & $\begin{array}{c}\mathrm{PM}_{2.5} \text { mass } \\
\text { concentration } \\
\left(\mu \mathrm{g} / \mathrm{m}^{3}\right)\end{array}$ & $\begin{array}{c}\text { Median value of particle } \\
\text { number }[0.3-20] \\
\left(\text { particle } / \mathrm{cm}^{3}\right)\end{array}$ \\
\hline $\begin{array}{c}\text { Pre- } \\
\text { occupancy }\end{array}$ & 7.4 & 33.5 & 12.1 & 408.0 \\
\hline $\begin{array}{c}\text { Summer } \\
2009\end{array}$ & 7.8 & 15.0 & 7.1 & 19.7 \\
\hline $\begin{array}{c}\text { Winter } \\
\text { 2009-2010 }\end{array}$ & 27.8 & n.a. & 23.5 & 137.5 \\
\hline $\begin{array}{c}\text { Summer } \\
2010\end{array}$ & 9.5 & 26.8 & n.a. & 42.3 \\
\hline $\begin{array}{c}\text { Winter } \\
\text { 2010-2011 }\end{array}$ & 74.7 & 166.1 & n.a. & 95.1 \\
\hline $\begin{array}{c}\text { Summer } \\
2011\end{array}$ & 7.5 & 16.3 & 8.4 & n.a. \\
\hline $\begin{array}{c}\text { Winter } \\
\text { 2011-2012 }\end{array}$ & 25.0 & 32.7 & 9.8 & n.a. \\
\hline
\end{tabular}




\section{ACCEPTED MANUSCRIPT}

Table 7 - Weekly mean indoor temperature $\left({ }^{\circ} \mathrm{C}\right)$ and absolute humidity $(\mathrm{g} / \mathrm{kg}) \pm$ standard deviation measured in the main bedroom and in the kitchen/living room at each house during occupancy by season. (n.a.: not available)

\begin{tabular}{|c|c|c|c|c|c|c|c|c|}
\hline & \multicolumn{4}{|c|}{ Temperature $\left({ }^{\circ}\right.$ C) } & \multicolumn{3}{c|}{ Absolute humidity (g/kg) } \\
\hline & \multicolumn{2}{|c|}{ House B } & \multicolumn{2}{c|}{ House E } & \multicolumn{2}{c|}{ House B } & \multicolumn{2}{c|}{ House E } \\
\hline Bedroom & $\begin{array}{c}\text { Kitchen/living } \\
\text { room }\end{array}$ & $\begin{array}{c}\text { Main } \\
\text { bedroom }\end{array}$ & $\begin{array}{c}\text { Kitchen/living } \\
\text { room }\end{array}$ & $\begin{array}{c}\text { Main } \\
\text { Bedroom }\end{array}$ & $\begin{array}{c}\text { Kitchen/living } \\
\text { room }\end{array}$ & $\begin{array}{c}\text { Main } \\
\text { Bedroom }\end{array}$ & $\begin{array}{c}\text { Kitchen/living } \\
\text { room }\end{array}$ \\
\hline $\begin{array}{c}\text { Summer } \\
\mathbf{2 0 0 9}\end{array}$ & $24.2 \pm 1.5$ & $23.4 \pm 1.9$ & $21.6 \pm 1.1$ & $22.7 \pm 1.6$ & $8.5 \pm 1.5$ & $8.2 \pm 1.5$ & $9.2 \pm 1.5$ & $9.0 \pm 1.4$ \\
\hline $\begin{array}{c}\text { Winter } \\
\mathbf{2 0 0 9 - 2 0 1 0}\end{array}$ & n.a. & n.a. & n.a. & n.a. & n.a. & n.a. & n.a. & n.a. \\
\hline $\begin{array}{c}\text { Summer } \\
\mathbf{2 0 1 0}\end{array}$ & $25.3 \pm 1.6$ & $24.4 \pm 1.4$ & $22.3 \pm 0.8$ & $22.6 \pm 0.8$ & $8.6 \pm 1.2$ & $8.6 \pm 1.2$ & $9.2 \pm 1.0$ & $9.0 \pm 0.9$ \\
\hline $\begin{array}{c}\text { Winter } \\
\mathbf{2 0 1 0 - 2 0 1 1}\end{array}$ & $18.7 \pm 1.4$ & $18.2 \pm 1.1$ & $15.9 \pm 1.0$ & $16.9 \pm 1.4$ & $6.3 \pm 0.7$ & $5.8 \pm 0.6$ & $5.1 \pm 0.6$ & $5.0 \pm 0.7$ \\
\hline $\begin{array}{c}\text { Summer } \\
\mathbf{2 0 1 1}\end{array}$ & $23.9 \pm 1.3$ & $24.4 \pm 1.3$ & $21.7 \pm 0.9$ & $22.1 \pm 1.2$ & $9.9 \pm 1.2$ & $10.0 \pm 1.1$ & $10.4 \pm 1.0$ & $10.1 \pm 0.9$ \\
\hline $\begin{array}{c}\text { Winter } \\
\mathbf{2 0 1 1 - 2 0 1 2}\end{array}$ & $21.8 \pm 1.1$ & $21.0 \pm 0.8$ & $17.5 \pm 0.6$ & $18.8 \pm 1.1$ & $7.9 \pm 0.6$ & $7.6 \pm 0.4$ & $7.7 \pm 0.5$ & $7.5 \pm 0.5$ \\
\hline
\end{tabular}


Table 8 - Concentrations of the most frequent VOCs and aldehydes measured in this study for each occupied house compared with the results of previous studies conducted in newly built, wooden framed, energy-efficient dwellings (n.m.: not measured)

\begin{tabular}{|c|c|c|c|c|c|c|c|c|c|c|}
\hline & Our study & Our study & [5] & [5] & [9] & [10] & [11] & [11] & [12] & [12] \\
\hline $\begin{array}{l}\text { Construction } \\
\text { type and energy } \\
\text { characteristics } \\
\text { (building's } \\
\text { name) }\end{array}$ & $\begin{array}{l}\text { Energy- } \\
\text { efficient } \\
\text { single } \\
\text { detached } \\
\text { house (B) }\end{array}$ & $\begin{array}{l}\text { Energy- } \\
\text { efficient } \\
\text { single } \\
\text { detached } \\
\text { house (E) }\end{array}$ & $\begin{array}{l}\text { BRE Low- } \\
\text { energy single } \\
\text { detached } \\
\text { house }\left(\mathrm{T}_{1}\right)\end{array}$ & $\begin{array}{c}\text { BRE Low- } \\
\text { energy single } \\
\text { detached } \\
\text { house }\left(\mathrm{T}_{2}\right)\end{array}$ & $\begin{array}{l}\text { Minergie } \\
\text { single } \\
\text { detached } \\
\text { house } \\
\text { (Berne) }\end{array}$ & $\begin{array}{c}\text { Four Zero } \\
\text { Carbon } \\
\text { houses }(1,2 \text {, } \\
3,4)\end{array}$ & $\begin{array}{c}\text { Net Zero } \\
\text { Energy } \\
\text { single } \\
\text { detached } \\
\text { house (Stow) }\end{array}$ & $\begin{array}{c}\text { Net Zero } \\
\text { Energy } \\
\text { single } \\
\text { detached } \\
\text { house } \\
\text { (Townsend) }\end{array}$ & $\begin{array}{l}\text { Low-energy } \\
\text { single } \\
\text { detached } \\
\text { house }\end{array}$ & $\begin{array}{l}\text { Near-zero- } \\
\text { energy } \\
\text { apartment }\end{array}$ \\
\hline $\begin{array}{c}\text { Occupation and } \\
\text { furnishing }\end{array}$ & $\begin{array}{l}\text { occupied } \\
\text { furnished }\end{array}$ & $\begin{array}{l}\text { occupied } \\
\text { furnished }\end{array}$ & $\begin{array}{l}\text { unoccupied } \\
\text { furnished }\end{array}$ & $\begin{array}{l}\text { unoccupied } \\
\text { furnished }\end{array}$ & $\begin{array}{l}\text { occupied } \\
\text { furnished }\end{array}$ & $\begin{array}{l}\text { occupied } \\
\text { furnished }\end{array}$ & $\begin{array}{l}\text { occupied } \\
\text { furnished }\end{array}$ & $\begin{array}{l}\text { occupied } \\
\text { furnished }\end{array}$ & $\begin{array}{l}\text { unoccupied, } \\
\text { unfurnished }\end{array}$ & $\begin{array}{l}\text { unoccupied } \\
\text { unfurnished }\end{array}$ \\
\hline $\begin{array}{c}\text { Strategy of } \\
\text { measurement } \\
\text { after completion }\end{array}$ & $\begin{array}{c}6 \text { weeks of } \\
\text { passive } \\
\text { sampling } \\
\text { over } 3 \text { years }\end{array}$ & $\begin{array}{c}6 \text { weeks of } \\
\text { passive } \\
\text { sampling } \\
\text { within } 3 \\
\text { years }\end{array}$ & $\begin{array}{c}28 \text { periods of } \\
28 \text { days of } \\
\text { passive } \\
\text { sampling } \\
\text { over } 2 \text { years }\end{array}$ & $\begin{array}{c}28 \text { periods of } \\
28 \text { days of } \\
\text { passive } \\
\text { sampling } \\
\text { over } 2 \text { years }\end{array}$ & $\begin{array}{l}4 \text { weeks of } \\
\text { passive } \\
\text { samplings } \\
\text { over } 1 \text { year }\end{array}$ & $\begin{array}{l}3 \text { periods of } \\
\text { active } \\
\text { sampling }\end{array}$ & $\begin{array}{c}3 \\
\text { consecutive } \\
\text { one-week } \\
\text { passive } \\
\text { sampling }\end{array}$ & $\begin{array}{c}3 \\
\text { consecutive } \\
\text { one-week } \\
\text { passive } \\
\text { sampling }\end{array}$ & $\begin{array}{l}1 \text { day of } \\
\text { active } \\
\text { sampling }\end{array}$ & $\begin{array}{c}1 \text { week of } 12 \\
\text { active } \\
\text { samplings }\end{array}$ \\
\hline $\begin{array}{c}\text { Indoor } \\
\text { concentrations } \\
\text { of VOCs and } \\
\text { aldehydes }\end{array}$ & $\begin{array}{c}\text { Mean } \\
\text { concentration } \\
\pm \text { standard } \\
\text { deviation }\end{array}$ & $\begin{array}{c}\text { Mean } \\
\text { concentration } \\
\pm \text { standard } \\
\text { deviation }\end{array}$ & $\begin{array}{l}\text { Mean } \\
\text { concentration } \\
\text { during the } \\
\text { first year/ the } \\
\text { second year }\end{array}$ & $\begin{array}{l}\text { Mean } \\
\text { concentration } \\
\text { during the } \\
\text { first year/ the } \\
\text { second year }\end{array}$ & $\begin{array}{c}\text { Mean } \\
\text { concentration } \\
\pm \text { standard } \\
\text { deviation }\end{array}$ & $\begin{array}{c}\text { Mean } \\
\text { concentration } \\
\pm \text { standard } \\
\text { deviation }\end{array}$ & $\begin{array}{c}\text { Range of } \\
\text { concentration } \\
\text { measured in } \\
\text { main } \\
\text { bedroom }\end{array}$ & $\begin{array}{l}\text { Range of } \\
\text { concentration } \\
\text { measured in } \\
\text { main } \\
\text { bedroom }\end{array}$ & $\begin{array}{c}\text { Measured } \\
\text { concentration }\end{array}$ & $\begin{array}{c}\text { Mean } \\
\text { concentration } \\
\pm \text { standard } \\
\text { deviation }\end{array}$ \\
\hline
\end{tabular}




\begin{tabular}{|c|c|c|c|c|c|c|c|c|c|c|}
\hline & & & & & & & $\begin{array}{c}\text { according } 3 \\
\text { ventilation } \\
\text { rates }\end{array}$ & $\begin{array}{c}\text { according } 3 \\
\text { ventilation } \\
\text { rates }\end{array}$ & & \\
\hline $\begin{array}{c}\qquad 1,2,4- \\
\text { trimethylbenzene }\end{array}$ & $4.2 \pm 1.6$ & $4.6 \pm 2.8$ & n.m. & n.m. & n.m. & n.m. & $0.7-1.1$ & $1.2-1.9$ & n.m. & n.m. \\
\hline Benzene & $1.9 \pm 1.2$ & $1.3 \pm 1.2$ & $27 / 4$ & $5 / 5$ & n.m. & n.m. & $0.0-21.9$ & $2.8-21.6$ & 3.1 & \multirow{5}{*}{$13 \pm 2^{\mathrm{c}}$} \\
\hline Ethylbenzene & $3.6 \pm 4.7$ & $4.2 \pm 2.3$ & n.m. & n.m. & $23 \pm 17^{\mathrm{a}}$ & n.m. & n.m. & n.m. & n.m. & \\
\hline Toluene & $6.1 \pm 2.5$ & $6.6 \pm 4.8$ & $19 / 6$ & $12 / 6$ & $30 \pm 23$ & n.m. & $8.6-10.9$ & $12.4-20.6$ & 11.6 & \\
\hline $\mathrm{m}+\mathrm{p}$-Xylene & $9.4 \pm 14.2$ & $8.4 \pm 7.7$ & $81 / 25^{b}$ & $64 / 21^{b}$ & & n.m. & $2.2-3.8$ & $3.5-7.0$ & 20.8 & \\
\hline o-Xylene & $3.3 \pm 5.0$ & $5.2 \pm 2.6$ & & & $12 \pm 5$ & n.m. & $2.4-2.7$ & $1.9-3.5$ & n.m. & \\
\hline n-Decane & $3.8 \pm 6.1$ & $4.2 \pm 5.4$ & n.m. & n.m. & $22 \pm 20$ & n.m. & $2.5-3.3$ & $4.2-7.8$ & n.m. & n.m. \\
\hline n-Undecane & $5.5 \pm 9.3$ & $5.9 \pm 10.1$ & $75 / 18$ & $70 / 17$ & $33 \pm 25$ & n.m. & $5.5-7.0$ & $3.9-6.9$ & n.m. & n.m. \\
\hline Acetaldéhyde & $15.7 \pm 8.7$ & $27.6 \pm 14.3$ & n.m. & n.m. & $35 \pm 54$ & n.m. & $40.6-41.8$ & $23.1-43.1$ & n.m. & $17 \pm 2$ \\
\hline Acrolein & $5.1 \pm 6.7$ & $2.4 \pm 0.6$ & n.m. & n.m. & $1 \pm 1$ & n.m. & n.m. & n.m. & n.m. & n.m. \\
\hline Benzaldehyde & $3.4 \pm 1.4$ & $4.0 \pm 3.9$ & n.m. & n.m. & $2 \pm 3$ & & $6.3-7.0$ & $6.1-6.7$ & n.m. & n.m. \\
\hline Formaldehyde & $27.8 \pm 5.3$ & $20.8 \pm 5.5$ & $59 / 42$ & $51 / 37$ & $9 \pm 6$ & $34 \pm 12$ & $25.7-29.1$ & $38.3-49.6$ & 34 & $43 \pm 15$ \\
\hline Hexaldehyde & $47.3 \pm 15.3$ & $99.4 \pm 26.6$ & n.m. & n.m. & $148 \pm 94$ & n.m. & 166-177 & $117-150$ & 48.9 & n.m. \\
\hline Alpha-pinene & $14.4 \pm 6.1$ & $14.7 \pm 8.7$ & n.m. & n.m. & $168 \pm 89$ & n.m. & $52.4-64.4$ & $26.2-41.1$ & 297 & \multirow{3}{*}{$54 \pm 10^{\mathrm{d}}$} \\
\hline Beta-pinene & $3.5 \pm 1.7$ & $5.2 \pm 2.4$ & n.m. & n.m. & $18 \pm 17$ & n.m. & n.m. & n.m. & n.m. & \\
\hline Limonene & $15.6 \pm 18.5$ & $11.8 \pm 6.4$ & n.m. & n.m. & $96 \pm 20$ & n.m. & $19.8-26.1$ & $15.8-25.4$ & 64.7 & \\
\hline n-butylacetate & $186,5 \pm 313.1$ & $4.2 \pm 3.1$ & n.m. & n.m. & $3 \pm 1$ & n.m. & n.m. & n.m. & n.m. & n.m. \\
\hline
\end{tabular}




\section{${ }^{a}$ for ethylbenzene and m-xylene}

${ }^{b}$ for xylenes

${ }^{c}$ for BTEX

${ }^{\mathrm{d}}$ for alpha-pinene, beta-pinene, 3-carene and limonene 


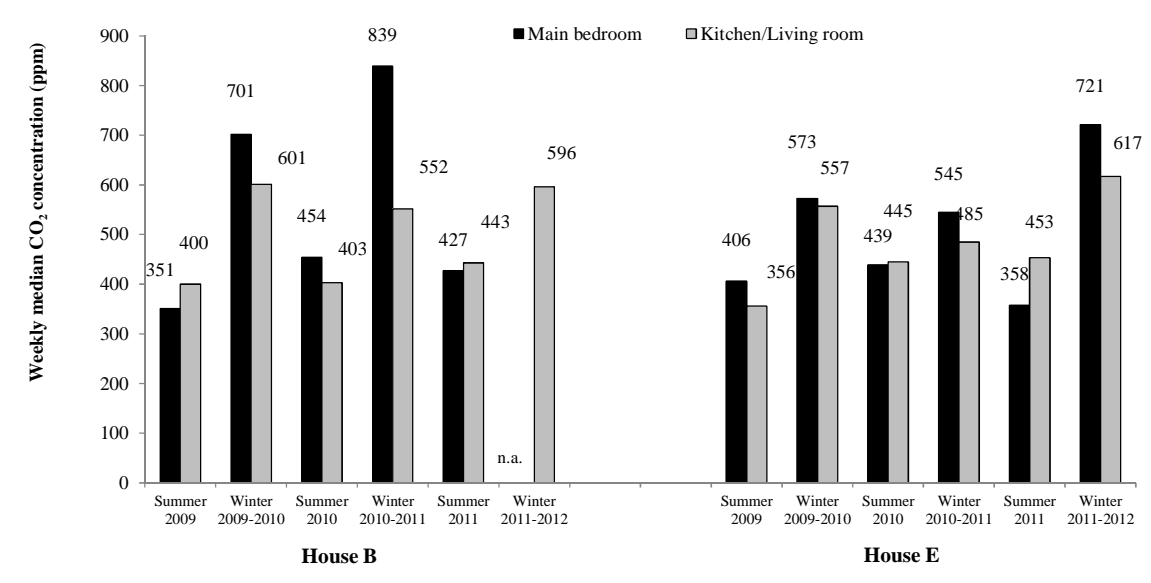

Figure 1 - Weekly median $\mathrm{CO}_{2}$ concentration (ppm) measured in the main bedroom (black columns) and in the kitchen/living room (grey columns) of each occupied house by season (n.a.: not available).
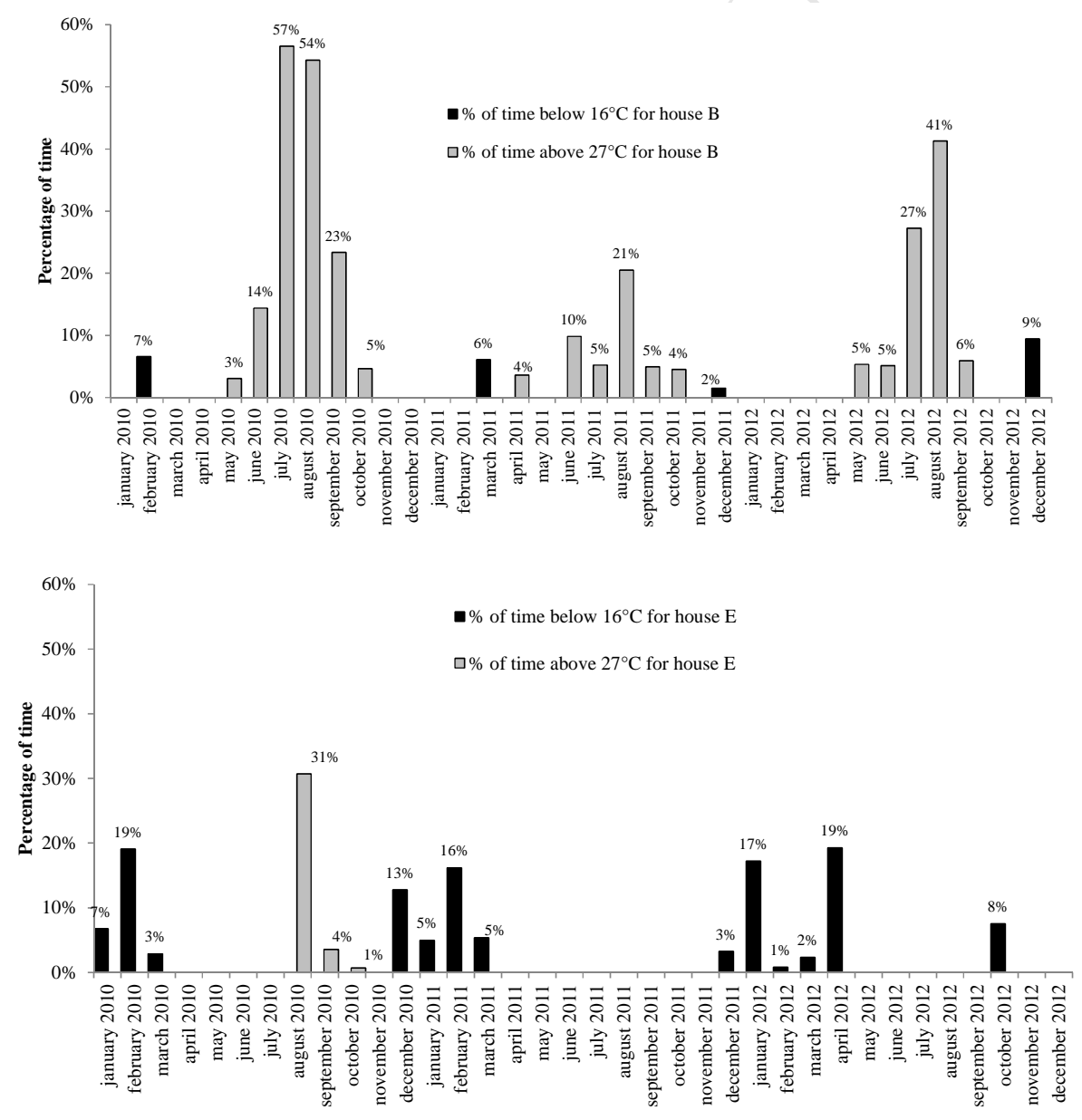

Figure 2 - Percentage of time per month when the indoor temperature measured in the kitchen/living room of house $\mathrm{B}$ (upper) and house $\mathrm{E}$ (lower) was below $16^{\circ} \mathrm{C}$ (black columns) or above $27^{\circ} \mathrm{C}$ (grey columns) over 2 years. 


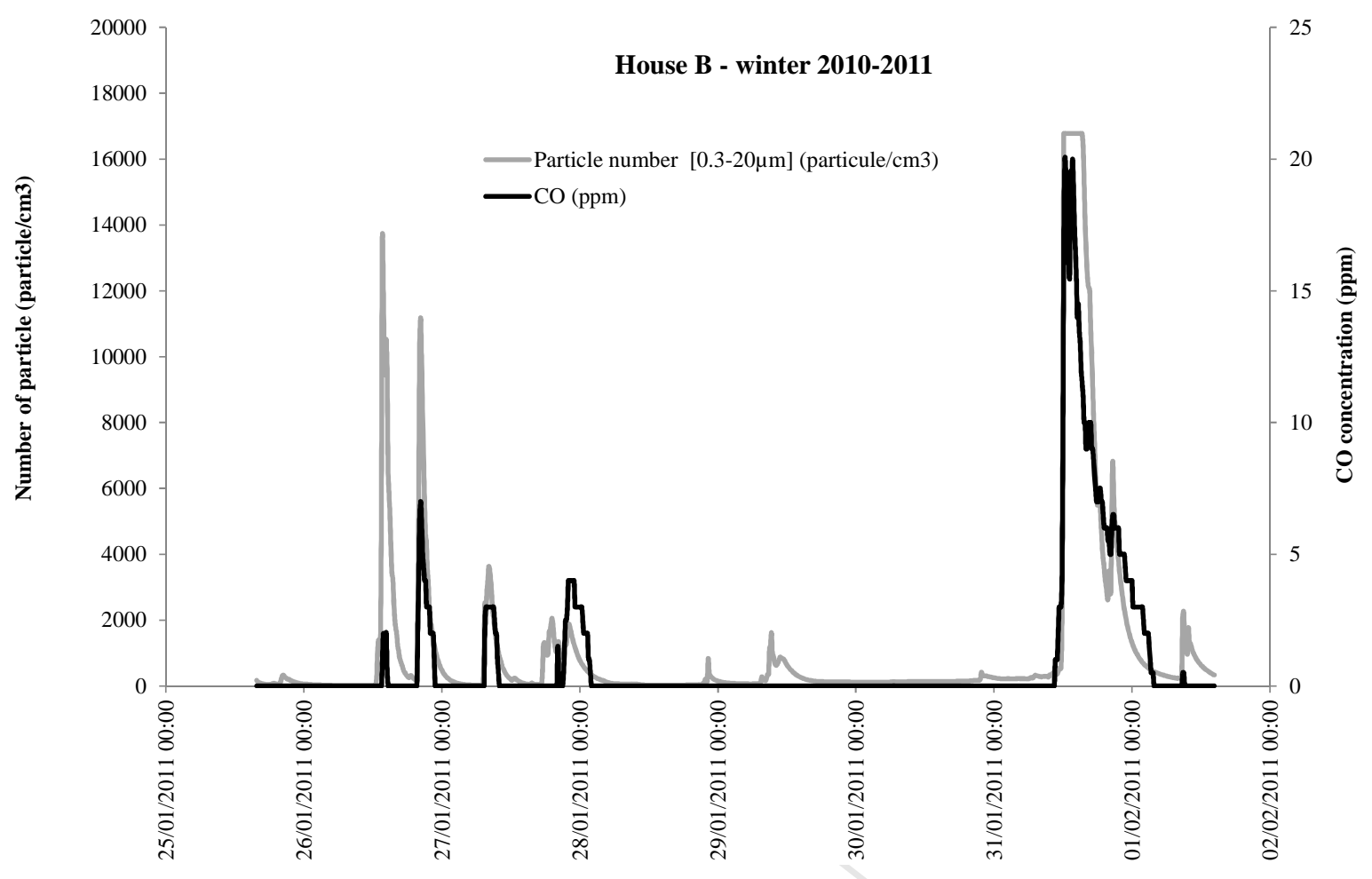

Figure 3 - Variations in particle number (particle $/ \mathrm{cm}^{3}$ ) (grey line) and CO concentration (ppm) (black line) measured every ten minutes in the kitchen/living room of house B during the week of investigation in winter 2010-2011. 


\section{Highlights:}

- Indoor environmental quality (IEQ) in energy-efficient houses was studied over time

- IEQ was generally acceptable over time except when ventilation systems were shut down

- More quiet, user-friendly and robust ventilation systems have to be developed

- Inspection of ventilation systems and frequent maintenance by professional should be mandatory

- Information should be provide to the user to avoid some behaviour leading to poor IEQ 